Check for updates

Cite this: RSC Adv., 2019, 9, 16496

Received 12th April 2019

Accepted 21st May 2019

DOI: $10.1039 / c 9 r a 02757 b$

rsc.li/rsc-advances

\section{Catalytic degradation of diclofenac from aqueous solutions using peroxymonosulfate activated by magnetic $\mathrm{MWCNTs}-\mathrm{CoFe}_{3} \mathrm{O}_{4}$ nanoparticles}

\author{
Yousef Dadban Shahamat, ${ }^{a}$ Mohammad Ali Zazouli, ${ }^{b}$ Mohammad Reza Zare ${ }^{c}$ \\ and Nezamaddin Mengelizadeh (iD *d
}

$\mathrm{CoFe}_{3} \mathrm{O}_{4}$ nanoparticles supported on multi-walled carbon nanotubes (MWCNTs-CoFe ${ }_{3} \mathrm{O}_{4}$ ) were synthesized by the co-precipitation method as a novel catalyst for degradation of diclofenac (DCF). The comparative experiments indicated that $\mathrm{MWCNTs}-\mathrm{CoFe}_{3} \mathrm{O}_{4}$ has a better catalytic activity in degradation of DCF and activation of peroxymonosulfate (PMS) compared to other catalytic systems. This can be attributed to the interaction of $\mathrm{MWCNTs}$ with $\mathrm{CoFe}_{3} \mathrm{O}_{4}$ in accelerating the absorption process and activating the PMS $\left(E_{a}=22.93 \mathrm{~kJ} \mathrm{~mol}^{-1}\right)$. The removal efficiencies of DCF and total organic carbon (TOC) were $99.04 \%$ and $50.11 \%$, under optimum conditions, e.g., pH of 7, PMS dosage of $4 \mathrm{mM}$, DCF concentration of $30 \mathrm{mg} \mathrm{L}^{-1}$, catalyst dosage of $500 \mathrm{mg} \mathrm{L}^{-1}$, and reaction time of $120 \mathrm{~min}$. The oxidation of DCF was fitted by the pseudo-first-order kinetic model and the constant rate was increased by increasing the $\mathrm{pH}$, temperature, dosage of PMS and catalyst. The production of reactive species was studied using scavengers such as TBA and ethanol and the results showed that sulfate radical is the reactive species responsible for the degradation of DCF. The MWCNTs- $\mathrm{COFe}_{3} \mathrm{O}_{4}$ catalyst showed high stability and reusability based on five successful repeated reactions, $X$-ray diffraction and energy dispersive $X$-ray spectroscopy analysis. Based on the intermediates detected by gas chromatographymass spectrometry (GC-MS), the possible pathways for DCF catalytic oxidation were proposed. The results explained that the $\mathrm{PMS} / \mathrm{MWCNTS}-\mathrm{CoFe}_{3} \mathrm{O}_{4}$ system is a promising method for treating DCF solution due to high efficiency, good reusability of catalyst and greater PMS activation.

\section{Introduction}

Over the past decades, pharmaceuticals and personal care products have been widely found as emerging contaminants due to their widespread use for the treatment of human and animal diseases. ${ }^{\mathbf{1}}$ The worldwide consumption of drugs releases high amounts of the original compound or their metabolites into the environment. Recent studies towards the occurrence of these organic compounds indicate the presence of high amounts of pharmaceuticals belonging to different therapeutic groups in wastewater, surface water and groundwater due to their polar non-volatile nature., ${ }^{\mathbf{1 , 2}}$ The presence of such compounds in aquatic environments for a long time may result in bioaccumulation and negative effects on aquatic ecosystems

${ }^{a}$ Environmental Health Research Center, Department of Environmental Health Engineering, Faculty of Health, Golestan University of Medical Sciences, Gorgan, Iran ${ }^{b}$ Department of Environmental Health Engineering, Health Sciences Research Center, Faculty of Health, Mazandaran University of Medical Sciences, Sari, Iran

${ }^{c}$ Department of Environmental Health Engineering, Evaz Faculty of Health, Larestan University of Medical Sciences, Larestan, Iran

${ }^{d}$ Research Center of Health, Safety and Environment, Department of Environmental Health Engineering, Evaz Faculty of Health, Larestan University of Medical Sciences, Larestan, Iran. E-mail: nezam_m2008@yahoo.com; Tel: +98-939-231-2472 and human health. ${ }^{3}$ Diclofenac (DCF, 2-(2,6-dichlorophenylamino) phenylacetic acid) is one of the most important non-steroidal anti-inflammatory drugs (NSAIDs) with a total consumption of 1014 tons to treat inflammation and pain associated with rheumatic and non-rheumatic diseases. ${ }^{4,5}$ Due to its high stability and lower removal in sewage treatment plants, DCF has been found at a range from $n g \mathrm{~L}^{-1}$ to $\mu \mathrm{g} \mathrm{L}^{-1}$ in surface waters and groundwater. ${ }^{4-6}$ The accumulation of DCF in the environment or the food chain has toxic effects on various environmental species., ${ }^{7,8}$ Therefore, an effective method is needed to remove this drug from aqueous solutions.

In recent years, advanced oxidation processes based on the production of sulfate radical $\left(\mathrm{SO}_{4}^{*}\right)$ have considered as a promising method for the removal of persistent organic compounds due to high redox potential (2.5-3.1 V) and application in a wide range of $\mathrm{pH}^{4,9}$ Compared to hydroxyl radical $(\cdot \mathrm{OH}), \mathrm{SO}_{4}^{\cdot}$ has high selectivity and long lifetime $\left(\cdot \mathrm{OH}:<1 \mu \mathrm{s} ; \mathrm{SO}_{4}^{\cdot}: 30-40 \mu \mathrm{s}\right) .^{\mathbf{9}, 10}$ This reactive species can be produced via activating the persulfate or PMS by heat, UV, and metal ions such as cobalt, iron, and copper. ${ }^{10}$ Activation by transition metal such as cobalt (Co) has been widely investigated for the removal of various pollutants due to high reactivity, low cost and the lack of need for a complex reactor compared to energy-based activation 
methods., ${ }^{911}$ However, the application of the PMS/Co process has been limited due to the need for high dosage in the treatment of strong wastewater, hard separation and cobalt ion toxicity. ${ }^{12,13}$ To avoid problems associated with the PMS/Co homogeneous system, researchers have recently proposed cobalt loading on the solid support such as zeolite, ${ }^{\mathbf{1 4}}$ activated carbon, ${ }^{15}$ graphene, ${ }^{16}$ alumina ${ }^{17}$ and $\mathrm{TiO}_{2}{ }^{18}$.

Compared to the support materials mentioned above, carbon nanotubes (CNTs), as seamless cylinders of single or multi-layer graphene, have good physicochemical properties such as high surface area, good chemical stability, high thermal stability and good chelating with metals. ${ }^{19-22}$ These unique features have increased the tendencies for the application of $\mathrm{CNT}$ as metal supporting to remove various pollutants. ${ }^{23} \mathrm{Su}$ et al. coated the $\mathrm{Cu}_{3} \mathrm{~N}$ nanocrystal on carbon nanotubes and found that CNTs with a high specific surface area and high electronics activity facilitated the transfer of electrons for the oxygen reduction reaction by $\mathrm{Cu}_{3} \mathrm{~N}$ crystals. ${ }^{24}$ Pourzamani et al. reported that the presence of CNTs in the composite MWCNTs$\mathrm{Fe}_{3} \mathrm{O}_{4}$, in addition to preparing the required substrate for adsorbing and oxidizing the pollutants, produces more reactive oxygen species (ROSs) through the electrochemical reduction of oxygen..$^{21}$ However, PMS/CNTs-Co systems require the isolation or precipitation processes, which limit its full-scale application. ${ }^{25}$ In order to overcome these limitations, the magnetization of the composite was suggested by the researchers. ${ }^{26}$ Magnetic separation, due to easy recycling of the catalyst, lack of need for a centrifuge stage and the development of the specific surface area of catalyst for adsorption and oxidation, is considered as the efficient and rapid technology. ${ }^{27}$ In addition, some studies have reported the use of $\mathrm{Fe}_{3} \mathrm{O}_{4}$ for activation of PMS to produce ROSs. ${ }^{28}$ Liu et al. investigated the activation of PMS by the $\mathrm{MnO}_{2}-\mathrm{Fe}_{3} \mathrm{O}_{4}$ nanocomposite and observed that, by converting $\mathrm{Fe}^{2+}$ to $\mathrm{Fe}^{3+}$, the sulfate radical is produced by PMS activation. ${ }^{29}$ Tan et al. also reported that $\mathrm{Fe}^{2+}-\mathrm{Fe}^{3+}$ on the catalyst surface is the main factor for the activation of PMS and the production of $\cdot \mathrm{OH}$ and $\mathrm{SO}_{4}^{\cdot} \cdot{ }^{30}$

In spite of the good performance reported for CNTs and $\mathrm{Fe}_{3} \mathrm{O}_{4}$ and significant risk of DCF in aqueous solutions, removal of the DCF with $\mathrm{SO}_{4}^{-}$produced from activation of PMS using the MWCNTs-CoFe ${ }_{2} \mathrm{O}_{3}$ composite has scarcely studied. Therefore, in this study, the MWCNTs-CoFe ${ }_{3} \mathrm{O}_{4}$ catalyst was synthesized by the co-precipitation method and its physicochemical properties were determined by various techniques such as field emission scanning electron microscopy, transmission electron microscopy, X-ray diffraction, Fourier transform infrared spectroscopy and energy-dispersive X-ray spectroscopy. The performance of the PMS/MWCNTs-CoFe ${ }_{3} \mathrm{O}_{4}$ system in DCF degradation was evaluated by studying important parameters such as initial $\mathrm{pH}$, DCF concentration, PMS dosage, catalyst dosage, solution temperature and presence of various anions. Stability and reusability of the catalyst were investigated in five run cycles reaction. The reactive species were investigated by studying the catalytic activity of the process and the scavenging test. Finally, the intermediates of DCF degradation were identified by GC-MS and its degradation pathways were suggested.

\section{Experimental}

\section{Material and regents}

Potassium peroxymonosulfate (oxone, $2 \mathrm{KHSO}_{5} \cdot \mathrm{KHSO}_{4} \cdot \mathrm{K}_{2} \mathrm{SO}_{4}$, $>98 \%$ ), iron(III) chloride hexahydrate $\left(\mathrm{FeCl}_{3} \cdot 6 \mathrm{H}_{2} \mathrm{O}, 98 \%\right)$, cobalt(II) nitrate hexahydrate $\left(\mathrm{Co}\left(\mathrm{NO}_{3}\right)_{2} \cdot 6 \mathrm{H}_{2} \mathrm{O}, 98 \%\right)$, sodium hydroxide $(\mathrm{NaOH},>97 \%)$, chloroform $\left(\mathrm{CHCl}_{3}, \mathrm{HPLC}\right.$ grade, $>99.9 \%)$, acetone $\left(\mathrm{CH}_{3} \mathrm{COCH}_{3}, \mathrm{HPLC}\right.$ grade, $\left.>99.8 \%\right)$, and $\mathrm{N}$ trimethylsilyl $\mathrm{N}$-methyl trifluoroacetamide (MSTFA, $\mathrm{CF}_{3} \mathrm{CON}$ $\left(\mathrm{CH}_{3}\right) \mathrm{Si}\left(\mathrm{CH}_{3}\right)_{3}$, >98\%) was purchased from Sigma Aldrich. Diclofenac sodium salt $\left(\mathrm{C}_{14} \mathrm{H}_{10} \mathrm{Cl}_{2} \mathrm{NNaO}, 98 \%\right)$ was prepared from Sigma Aldrich as the studied pollutant. Multi-walled carbon nanotubes (MWCNTs, >110 $\mathrm{m}^{2} \mathrm{~g}^{-1}$, 95\%) were purchased from US research nanomaterials (Houston, USA). All solutions were prepared by purified water.

\section{Synthesis of MWCNTs-CoFe ${ }_{3} \mathrm{O}_{4}$}

The MWCNTs-CoFe ${ }_{3} \mathrm{O}_{4}$ nanoparticles were prepared, according to the co-precipitation method, reported by Oh et al. with some modifications. ${ }^{31}$ First, $0.45 \mathrm{~g} \mathrm{FeCl}_{3} \cdot 6 \mathrm{H}_{2} \mathrm{O}$ and $0.25 \mathrm{~g} \mathrm{Co}$ $\left(\mathrm{NO}_{3}\right)_{2} \cdot 6 \mathrm{H}_{2} \mathrm{O}$ were dissolved in $100 \mathrm{~mL}$ distilled water. $0.5 \mathrm{~g}$ of MWCNTs was added to the stirred solution with a magnetic stirrer for $1 \mathrm{~h}$. The $\mathrm{pH}$ of the solution was then adjusted to $\mathrm{pH}$ of 10-11 using $1 \mathrm{M} \mathrm{NaOH}$. The solution was stirred for $2 \mathrm{~h}$ at $100{ }^{\circ} \mathrm{C}$. After cooling the solution, the solid product was isolated using a magnetic field and washed several times with distilled water. Finally, the solid product was dried at $60{ }^{\circ} \mathrm{C}$ for $12 \mathrm{~h}$. MWCNTs- $\mathrm{Fe}_{3} \mathrm{O}_{4}$ nanoparticles were prepared under the same conditions without the addition of cobalt.

\section{Characteristics}

The structure and morphology of nanoparticles were determined by field emission scanning electron microscopy (FESEM, MIRA III model, TESCAN, Czech) and high-resolution transmission electron microscope (TEM, JEM-3000F). The crystalline structure of the synthesized catalyst was determined using an Xray diffractometer using a $\mathrm{Cu} \mathrm{K} \alpha$ radiation source which operated at $45 \mathrm{kV}$ and $40 \mathrm{~mA}$. The chemical compositions of the catalyst were analyzed by energy-dispersive X-ray (EDX) analysis coupled with MIRA III SEM. Functional groups and chemical bands were evaluated by Fourier transform infrared spectroscopy (FTIR, AVATAR model, USA) with a frequency range of 400$4000 \mathrm{~cm}^{-1}$. The point of zero charge of the nanoparticles was determined using the Zetasizer Nano analyzer (Malvern, UK).

\section{Catalytic degradation of DCF}

Diclofenac degradation experiments were performed in $250 \mathrm{~mL}$ conical flask containing $100 \mathrm{~mL}$ of the aqueous solution. An appropriate dose of MWCNTs-CoFe $\mathrm{O}_{4}$ and PMS was added to the flask containing a specific concentration of DCF solution. At different times, a sample was taken from the flask for analysis using GC-MS. The solution $\mathrm{pH}$ was adjusted by sulfuric acid $(0.1 \mathrm{M})$ and sodium hydroxide $(0.1 \mathrm{M})$. The effect of coexisting anions on DCF removal was studied in the presence of $\mathrm{NaCl}, \mathrm{NaNO}_{3}$ and $\mathrm{NaHCO}_{3}$. Quenching 
experiments were performed under the optimum conditions with tert-butyl alcohol (TBA) and methanol agents. The stability and reusability of nanoparticles were studied by repeated experiments under similar optimum conditions.

\section{Analytical methods}

The concentrations of DCF and its intermediates were measured by a GC-MS system (Agilent, USA) equipped with a DB-5 column. COD values were measured by low and high range COD ampoules with a spectrophotometer (DR 5000, $\mathrm{HACH}$ ). Total organic carbon (TOC) was analyzed by Shimadzu TOC Analyzer. The removal efficiency $(R)$ was calculated by eqn (1). Kinetics of DCF removal was described by the pseudo-firstorder equation (eqn (2)).

$$
\begin{gathered}
R=\frac{C_{0}-C_{\mathrm{e}}}{C_{0}} \times 100 \\
\ln \frac{C_{0}}{C_{\mathrm{e}}}=-K t
\end{gathered}
$$

where $C_{0}$ and $C_{\mathrm{e}}$ are the initial and final concentrations of DCF, respectively and $K$ is kinetic constant rate.

\section{Results and discussion}

\section{Characteristics of MWCNTs- $\mathrm{CoFe}_{3} \mathrm{O}_{4}$}

The morphology of MWCNTs and synthesized catalysts, i.e., MWCNTs- $\mathrm{Fe}_{3} \mathrm{O}_{4}$ and MWCNTs-CoFe ${ }_{3} \mathrm{O}_{4}$ have been obtained by SEM images and the results are shown in Fig. 1. It was observed that the $\mathrm{Fe}_{3} \mathrm{O}_{4}$ and $\mathrm{CoFe}_{3} \mathrm{O}_{4}$ nanoparticles were non-uniformly coated on the outer walls of the MWCNTs. In Fig. 2, TEM images showed the distribution of $\mathrm{Fe}_{3} \mathrm{O}_{4}$ and $\mathrm{CoFe}_{3} \mathrm{O}_{4}$ nanoparticles on the surface of MWCNTs. In addition, the EDX spectrum (Fig. 2c) confirmed the presence of iron, cobalt, carbon and oxygen in the prepared MWCNTs-CoFe ${ }_{3} \mathrm{O}_{4}$ nanoparticle. Fig. 2d confirms the magnetic properties of MWCNTs containing $\mathrm{CoFe}_{3} \mathrm{O}_{4}$ nanoparticles.

The XRD pattern of the MWCNTs, MWCNTs- $\mathrm{Fe}_{3} \mathrm{O}_{4}$, and MWCNTs-CoFe ${ }_{3} \mathrm{O}_{4}$ is shown in Fig. 3. As can be seen, in each of the three samples, there are two characteristic sharp peaks at $2 \theta$ $=26.13^{\circ}$ and $43.98^{\circ}$ which are related to the structure of the MWCNTs. For MWCNTs- $\mathrm{Fe}_{3} \mathrm{O}_{4}$, the diffraction peaks observed at $2 \theta=55.30^{\circ}, 35.86^{\circ}, 43.71^{\circ}$, and $57.88^{\circ}$ are related to $\mathrm{Fe}_{3} \mathrm{O}_{4}$ nanoparticles. ${ }^{26,27}$ These results were confirmed by the XRD peaks of $\mathrm{Fe}_{3} \mathrm{O}_{4}$ nanoparticles shown in Fig. 3. Compared to the catalysts mentioned above, the diffraction peaks of the MWCNTs-CoFe ${ }_{3} \mathrm{O}_{4}$ were broad, which indicates iron and cobalt are coated on MWCNTs.

Fig. 4 shows the FTIR absorption spectra of samples recorded in the range of $400-4000 \mathrm{~cm}^{-1}$. For MWCNTs, the bands of $1050 \mathrm{~cm}^{-1}, 1430 \mathrm{~cm}^{-1}, 1600 \mathrm{~cm}^{-1}, 2900 \mathrm{~cm}^{-1}$, and $3450 \mathrm{~cm}^{-1}$ are related to stretching modes and bending of $\mathrm{C}-\mathrm{O}, \mathrm{C}-\mathrm{C}, \mathrm{C}-\mathrm{O}$, $-\mathrm{CH}_{2}$ and $-\mathrm{OH}$. For the FTIR spectrum of the MWCNTs- $\mathrm{Fe}_{3} \mathrm{O}_{4}$ nanoparticle, except for the mentioned bands, there is a strong IR band near the wavelength of $570 \mathrm{~cm}^{-1}$, which is related to the Fe-O characteristic peak. ${ }^{26}$ These results were confirmed by the FTIR spectra of $\mathrm{Fe}_{3} \mathrm{O}_{4}$ nanoparticles shown in Fig. 4. In contrast, the MWCNTs-CoFe $\mathrm{O}_{4}$ spectra were weaker and smoother at some wavelengths, which is indicative of the changes in the MWCNTs surface due to the co-precipitation process. In this FTIR, strong absorption was observed between $600-500 \mathrm{~cm}^{-1}$ compared to MWCNTs, which indicates the formation of $\mathrm{CoFe}_{3} \mathrm{O}_{4}$ on the surface of MWCNTs. ${ }^{32-34}$

\section{The catalytic activity of $\mathrm{MWCNTs}-\mathrm{CoFe}_{3} \mathrm{O}_{4}$}

To evaluate the DCF catalytic degradation by MWCNTs$\mathrm{CoFe}_{3} \mathrm{O}_{4}$, a series of experiments were carried out using different catalysts in two absorption and degradation states. As can be seen in Fig. 5a, a small degradation of DCF occurred in the presence of PMS alone (2 mM). However, the DCF removal
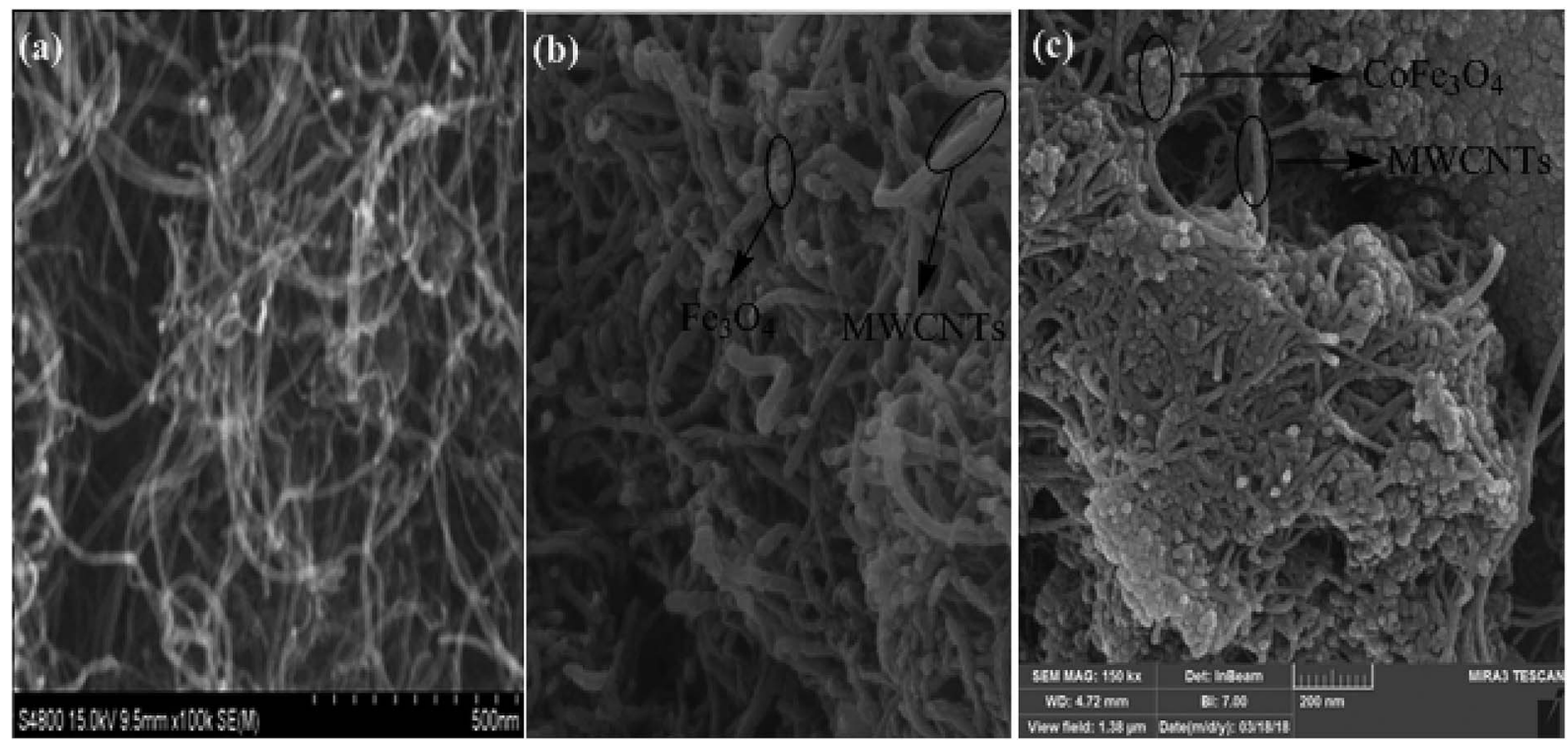

Fig. 1 SEM images of MWCNTs (a), MWCNTs- $\mathrm{Fe}_{3} \mathrm{O}_{4}$ (b) and MWCNTs- $\mathrm{CoFe}_{3} \mathrm{O}_{4}$ (c). 

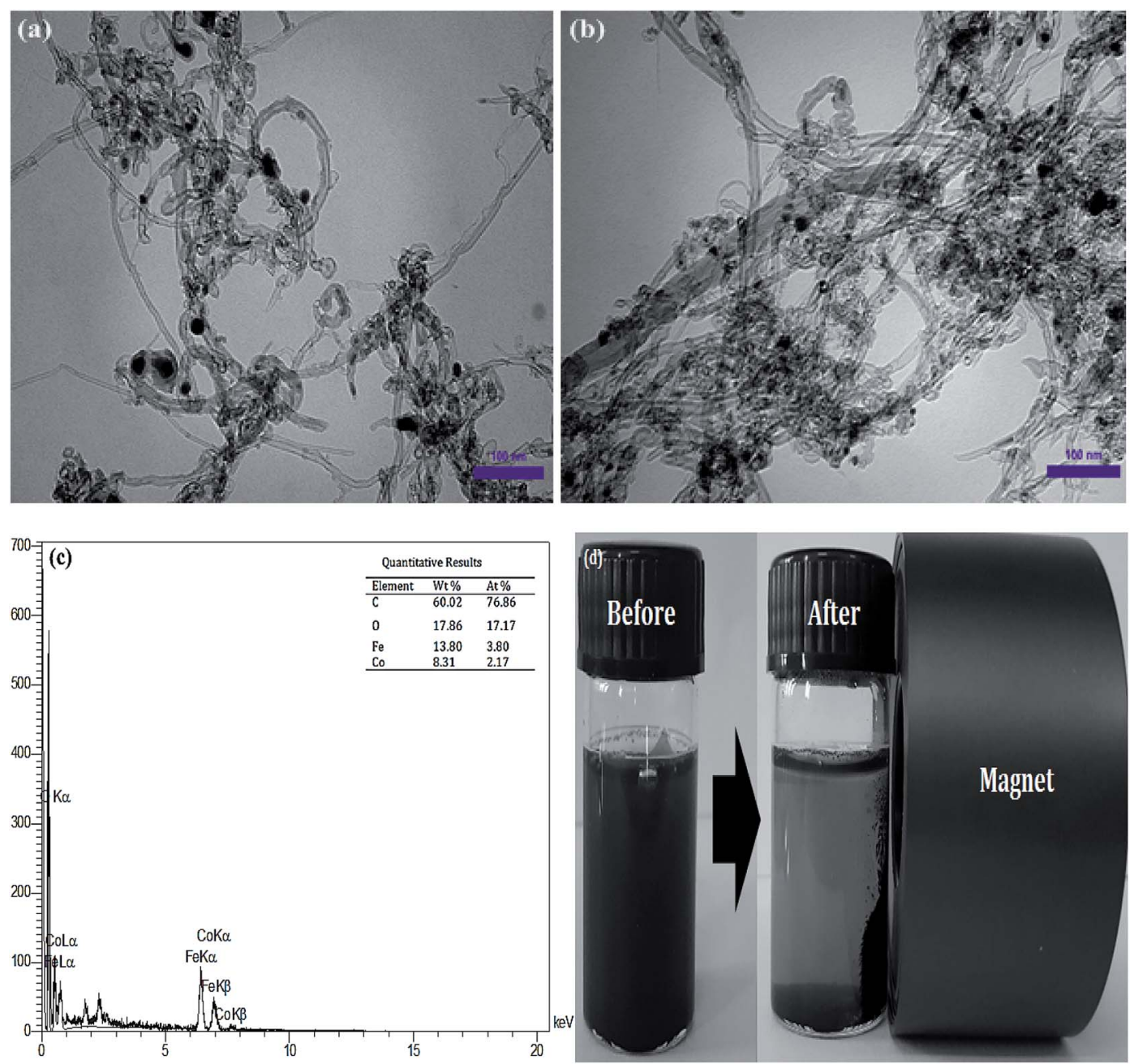

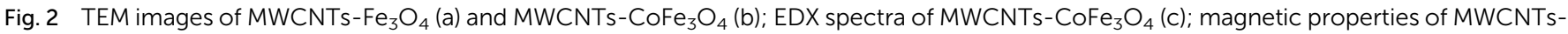
$\mathrm{CoFe}_{3} \mathrm{O}_{4}$ (d).

efficiency was obtained to be $64.26 \%$ and $60.10 \%$ using the MWCNTs and MWCNTs-CoFe ${ }_{3} \mathrm{O}_{4}$, respectively. This efficiency may be due to the high surface area of MWCNTs. A similar trend was reported by Hu and Cheng, ${ }^{35}$ Czech and Oleszczuk ${ }^{36}$ for the adsorption of DCF by MWCNTs. Addition of $\mathrm{Fe}_{3} \mathrm{O}_{4}$ to a solution containing DCF and PMS increased the DCF degradation

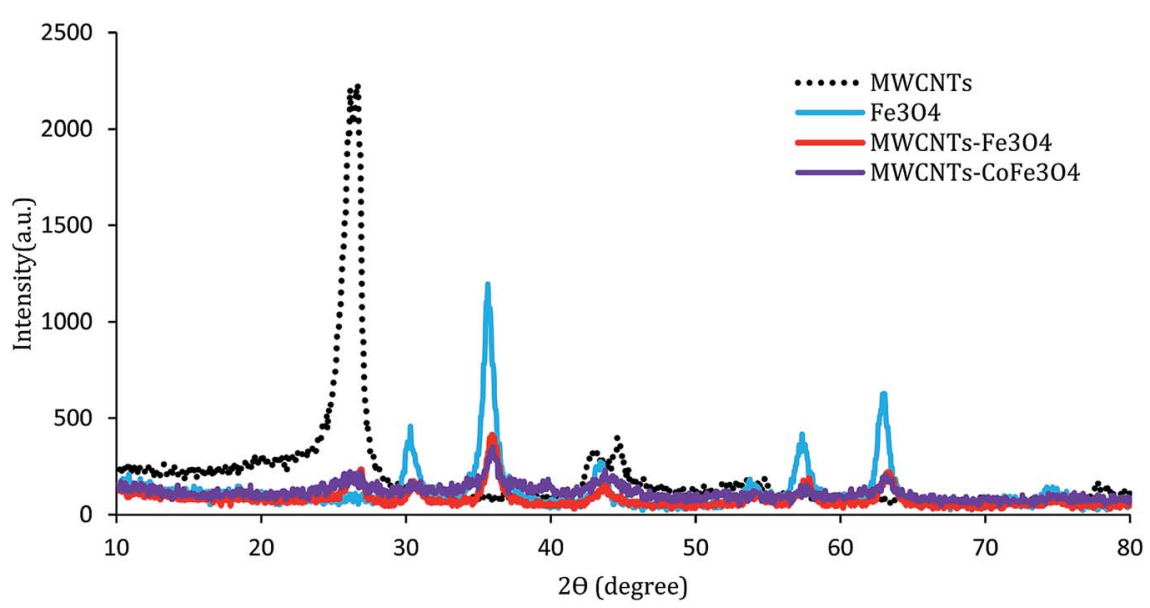

Fig. 3 XRD patterns of MWCNTs, $\mathrm{Fe}_{3} \mathrm{O}_{4}, \mathrm{MWCNTs}-\mathrm{Fe}_{3} \mathrm{O}_{4}$ and $\mathrm{MWCNTs}-\mathrm{CoFe}_{3} \mathrm{O}_{4}$. 


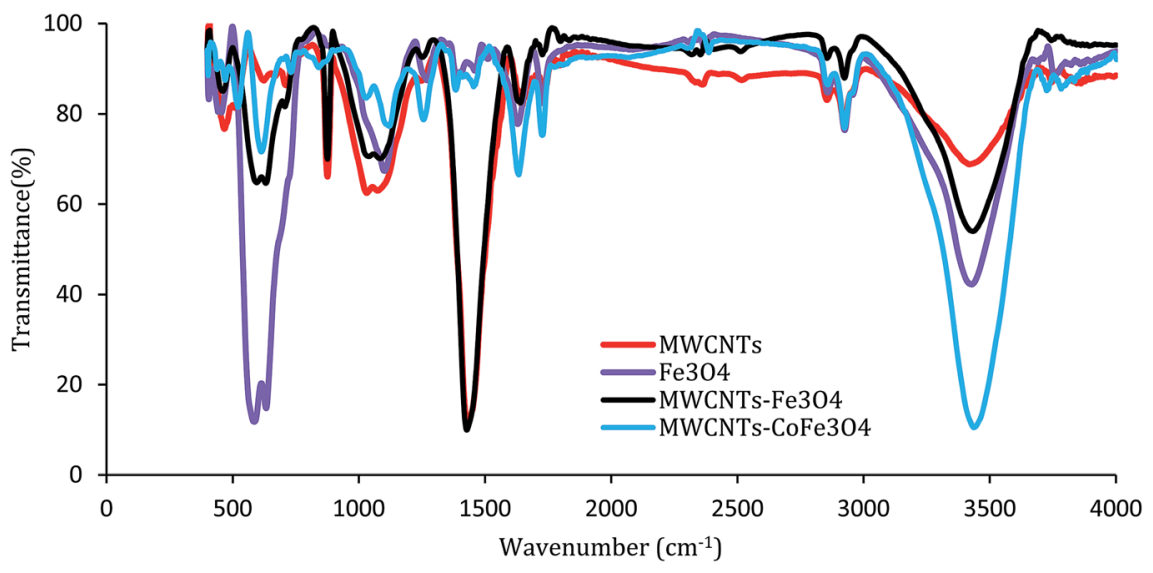

Fig. 4 FTIR spectrum of MWCNTs, $\mathrm{Fe}_{3} \mathrm{O}_{4}, \mathrm{MWCNTS}-\mathrm{Fe}_{3} \mathrm{O}_{4}$ and $\mathrm{MWCNTs}-\mathrm{CoFe}_{3} \mathrm{O}_{4}$.

efficiency to $66.83 \%$ at $120 \mathrm{~min}$. Tan et al. described this increase in efficiency based on the adsorption capacity of $\mathrm{Fe}_{3} \mathrm{O}_{4}$ nanoparticles and the production of $\cdot \mathrm{OH}$ and $\mathrm{SO}_{4}^{\cdot}$ by the reaction between $\mathrm{Fe}^{2+}$ ions on the catalyst surfaces and PMS (eqn (3)-(5)). ${ }^{30}$ Similar results were reported by Zhao et al. for the activation of PMS by $\mathrm{Fe}_{3} \mathrm{O}_{4}$ nanoparticles. ${ }^{37}$

It can also be seen in Fig. $5 \mathrm{a}$ that the performance of the MWCNTs/PMS system in removal of DCF is higher than the MWCNTs alone. This can be due to the production of reactive species through the reaction between PMS and CNTs. Similar results were reported by Chen $e t a l^{38}$ and Lee et al. ${ }^{39}$ about the activation of PMS and persulfate by CNTs, respectively. In addition, the results of Fig. 5a showed that the DCF removal efficiency in the homogeneous PMS/Co system at the initial time (15 and $30 \mathrm{~min}$ ) was much higher than the MWCNTs$\mathrm{CoFe}_{3} \mathrm{O}_{4} / \mathrm{PMS}$ system; but in the higher times, the removal rate was fixed and the complete degradation was not obtained compared to heterogeneous catalyst. In PMS/Co system, homogeneous cobalt can quickly react with PMS and lead to faster production of reactive species. This fast production of

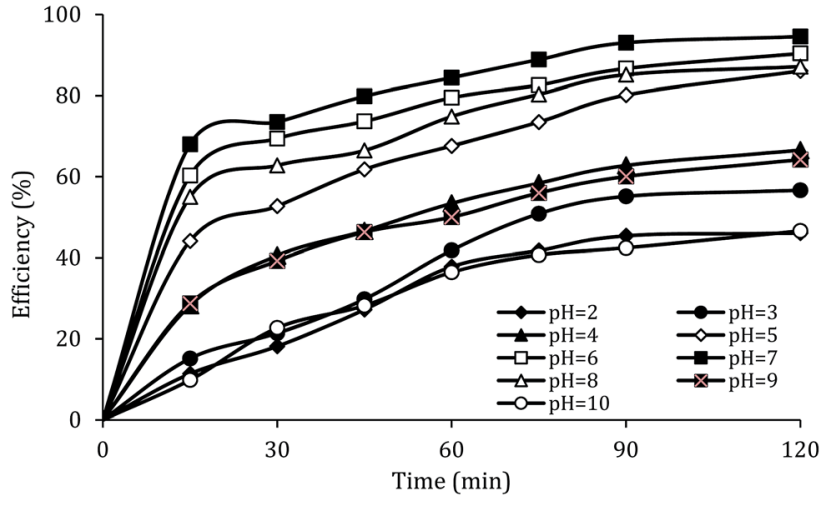

Fig. 6 Effect of solution $\mathrm{pH}$ on the removal efficiency of DCF.

radicals results in their loss by reacting with non-target molecules. In contrast, MWCNTs- $\mathrm{CoFe}_{3} \mathrm{O}_{4}$, with controlling the production of radicals during a long period of time, leads to a greater DCF removal than the PMS/Co system. These results
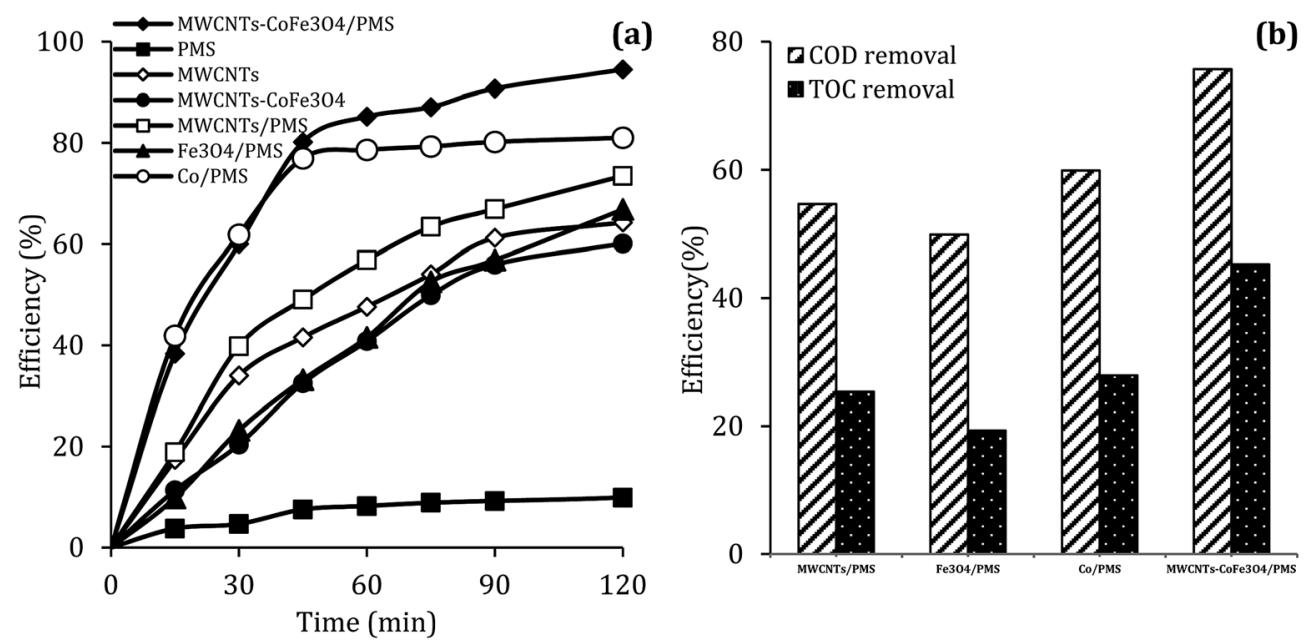

Fig. 5 The removal efficiency of DCF (a), COD and TOC (b) under different conditions (reaction conditions: $\mathrm{pH}=7, \mathrm{MWCNTs}-\mathrm{CoFe} \mathrm{O}_{4}=$ $\left.200 \mathrm{mg} \mathrm{L}^{-1}, \mathrm{Co}^{2+}=16.5 \mathrm{mg} \mathrm{L}^{-1}, \mathrm{PMS}=2 \mathrm{mM}, \mathrm{DCF}=30 \mathrm{mg} \mathrm{L}^{-1}\right)$. 
Table 1 The kinetic parameters for different operating conditions

\begin{tabular}{lll}
\hline Parameters & $k / \mathrm{min}^{-1}$ & $R^{2}$ \\
\hline $\mathrm{pH}$ &
\end{tabular}

$\mathrm{pH}$

2
3
4
5
6
7
8
9
10
Catalyst dosage $\left(\mathrm{mg} \mathrm{L}^{-1}\right)$

25

100

250

500

750

1000

PMS dosage $\left(\mathrm{mg} \mathrm{L}^{-1}\right)$

0.25
0.5
1
2
4
6
8
DCF concentration $\left(\mathrm{mg} \mathrm{L}^{-1}\right)$

10
20
30
50
Temperature $\left({ }^{\circ} \mathrm{C}\right)$

10

20

25

30

Other conditions: catalyst $=$ $200 \mathrm{mg} \mathrm{L}^{-1}, \mathrm{PMS}=2 \mathrm{mM}$, $\mathrm{DCF}=30 \mathrm{mg} \mathrm{L}^{-1}$

$0.005 \quad 0.923$

$0.007 \quad 0.949$

$0.008 \quad 0.929$

$\begin{array}{ll}0.015 & 0.969\end{array}$

$0.017 \quad 0.904$

$0.022 \quad 0.920$

$0.015 \quad 0.914$

$0.009 \quad 0.919$

$0.005 \quad 0.938$

Other conditions: $\mathrm{pH}=7$,

$\mathrm{PMS}=2 \mathrm{mM}, \mathrm{DCF}=$

$30 \mathrm{mg} \mathrm{L}^{-1}$

$0.010 \quad 0.960$

$0.015 \quad 0.977$

$0.019 \quad 0.969$

$0.024 \quad 0.922$

$0.024 \quad 0.919$

$0.015 \quad 0.966$

Other conditions: $\mathrm{pH}=7$,

catalyst $=500 \mathrm{mg} \mathrm{L}^{-1}, \mathrm{DCF}$ $=30 \mathrm{mg} \mathrm{L}^{-1}$

$0.009 \quad 0.989$

$0.011 \quad 0.983$

$0.015 \quad 0.960$

$0.021 \quad 0.922$

$0.032 \quad 0.926$

$0.018 \quad 0.891$

$0.017 \quad 0.986$

Other conditions: $\mathrm{pH}=7$,

catalyst $=500 \mathrm{mg} \mathrm{L}^{-1}$, PMS

$=4 \mathrm{mM}$

$0.038 \quad 0.968$

$0.032 \quad 0.923$

$0.032 \quad 0.926$

0.0120 .983

Other conditions: $\mathrm{pH}=7$,

catalyst $=500 \mathrm{mg} \mathrm{L}^{-1}$, PMS

$=4 \mathrm{mM}, \mathrm{DCF}=30 \mathrm{mg} \mathrm{L}^{-1}$

$0.016 \quad 0.985$

$0.018 \quad 0.954$

$0.022 \quad 0.932$

$0.032 \quad 0.926$

emphasize the role of the interaction between MWCNTs, $\mathrm{Fe}_{3} \mathrm{O}_{4}$ and Co on nanocatalysts.

$$
\begin{gathered}
\mathrm{Fe}(\mathrm{II})+\mathrm{HSO}_{5}{ }^{-} \rightarrow \mathrm{Fe}(\mathrm{III})+\mathrm{SO}_{5}{ }^{2-}+\cdot \mathrm{OH} \\
\mathrm{Fe}(\mathrm{II})-{ }^{-} \mathrm{OH}+\mathrm{HSO}_{5}{ }^{-} \rightarrow \mathrm{Fe}(\mathrm{II})-(\mathrm{HO}) \mathrm{OSO}_{3}{ }^{-}+\mathrm{OH}^{-} \\
\mathrm{Fe}(\mathrm{II})-(\mathrm{HO}) \mathrm{OSO}_{3}{ }^{-} \rightarrow \mathrm{Fe}(\mathrm{II})-{ }^{-} \mathrm{OH}+\mathrm{SO}_{5}{ }^{-}
\end{gathered}
$$

Along with the removal of DCF, the removal rate of COD and TOC in degradation systems at a reaction time of 120 min was investigated. It is clear from the results of Fig. $5 \mathrm{~b}$ that the removal of COD and TOC using the MWCNTs-CoFe ${ }_{3} \mathrm{O}_{4}$ system was much

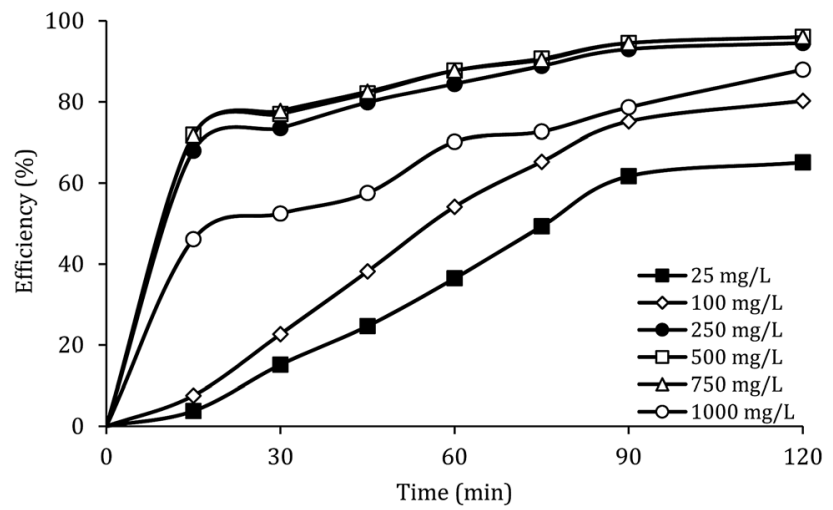

Fig. 7 Effect of MWCNTs- $\mathrm{CoFe}_{3} \mathrm{O}_{4}$ dosage on the removal efficiency of DCF.

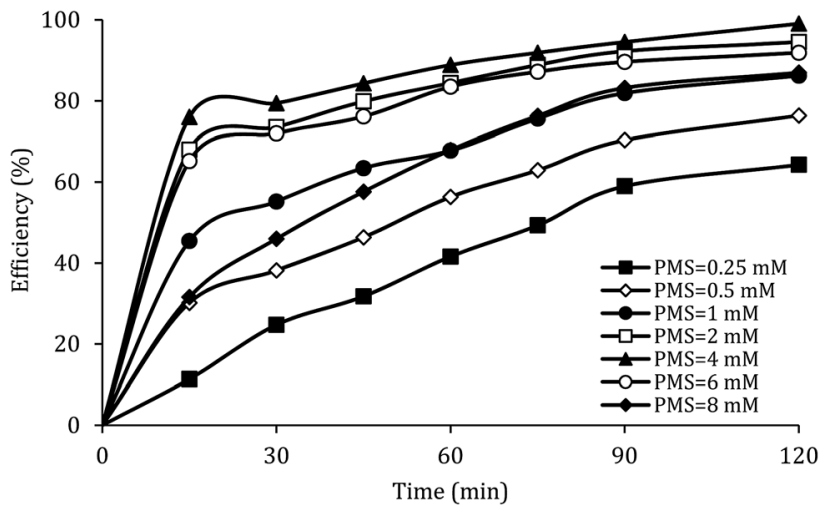

Fig. 8 Effect of PMS dosage on the removal efficiency of DCF.

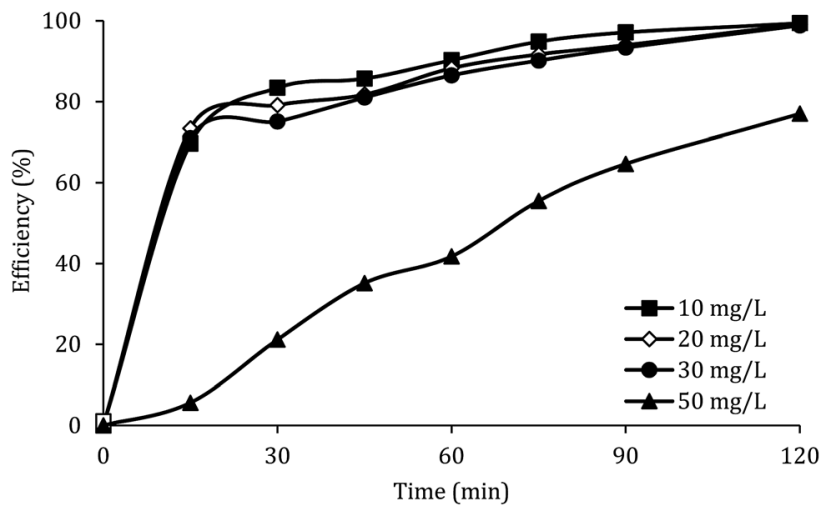

Fig. 9 Effect of initial DCF concentration on the removal efficiency of DCF.

higher than other catalytic systems. This high catalytic performance was due to the synergistic effect between $\mathrm{Fe}_{3} \mathrm{O}_{4}$, Co and MWCNTs for activation of PMS and adsorption of pollutant.

\section{The effect of initial pH}

The solution $\mathrm{pH}$, due to the effect on the properties of the catalyst surface and control of the production rate of reactive 

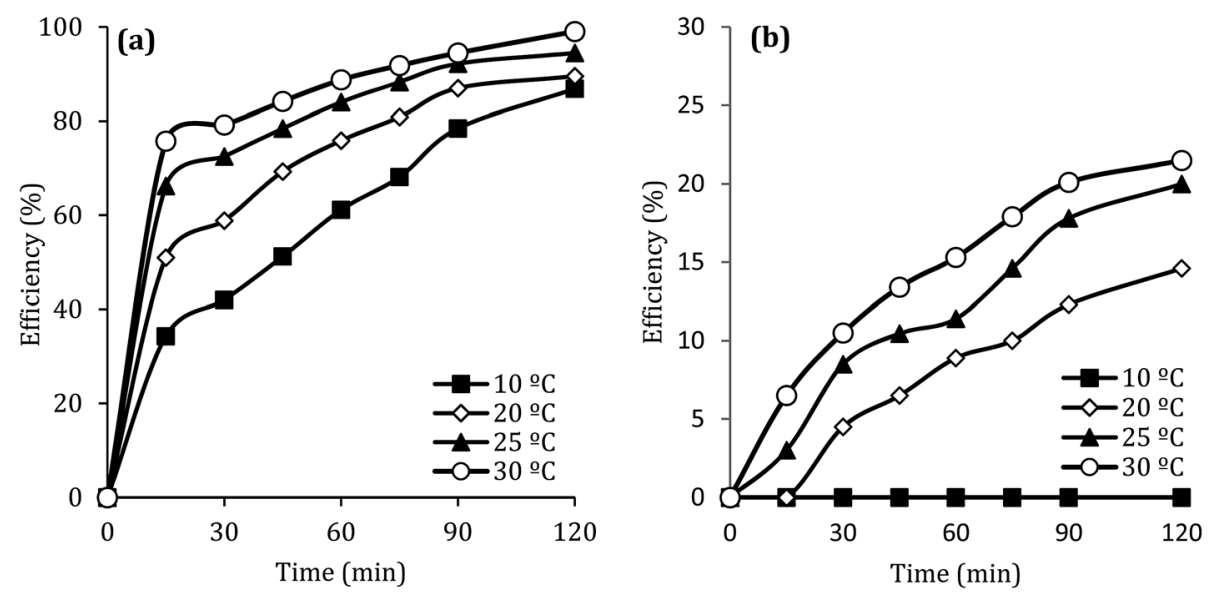

Fig. 10 Effect of temperature at presence (a) and without presence of catalyst (b) on the removal efficiency of DCF.

species $\left(\cdot \mathrm{OH}\right.$ and $\left.\mathrm{SO}_{4}^{\cdot}\right)$ and the concentration of transition metals ( $\mathrm{Co}$ and $\mathrm{Fe}$ ) is one of the important parameters in the PMS activation process. ${ }^{40}$ Therefore, the effect of the solution $\mathrm{pH}$ in the range of $2-10$ was studied under the condition including MWCNTs- $\mathrm{CoFe}_{3} \mathrm{O}_{4}$ of $200 \mathrm{mg} \mathrm{L}^{-1}$, PMS of $2 \mathrm{mM}$ and DCF of $30 \mathrm{mg} \mathrm{L}^{-1}$. The DCF removal efficiency gradually increased with an increase in the initial $\mathrm{pH}$ and then decreased with a further increase in $\mathrm{pH}$ (Fig. 6). The results of the kinetic analysis showed the same trends in DCF removal efficiency (Table 1). The kinetic constant rate was first improved from $0.005 \mathrm{~min}^{-1}$ to $0.022 \mathrm{~min}^{-1}$, when the initial $\mathrm{pH}$ increased from 2 to 7 and it was then decreased to $0.005 \mathrm{~min}^{-1}$ with increasing the $\mathrm{pH}$ to 10 . Increasing the efficiency at $\mathrm{pH} 7$ can be due to the production of the high concentration of $\mathrm{SO}_{4}^{\cdot}$ and $\cdot \mathrm{OH}$ through the reaction of PMS and cobalt ion. ${ }^{41}$ According to $\mathrm{Hu}$ et al. $\mathrm{p} K_{\mathrm{a} 2}$ of $\mathrm{H}_{2} \mathrm{SO}_{5}$ is 9.4, which means that, at the $\mathrm{pH}$ values lower than 9.4, PMS is mainly in the form of $\mathrm{HSO}_{5}{ }^{-}$. Under these conditions, most of the $\mathrm{HSO}_{5}{ }^{-}$ions react with cobalt ions $\left(\mathrm{Co}^{2+}\right)$ on the surface of the catalyst and produce high concentrations of reactive species. ${ }^{42}$ In addition, increasing the removal efficiency can be related to the electrostatic adsorption between the positive charge of the MWCNTs- $\mathrm{CoFe}_{3} \mathrm{O}_{4}$ catalyst and the negative charge of DCF. According to the studies, the surface charge of the materials depends on their $\mathrm{pH}_{\mathrm{pzc}}$ and the solution $\mathrm{pH}$. The surface of the materials is positive when $\mathrm{pH}_{\mathrm{pzc}}$ is higher than the solution $\mathrm{pH}$ and the negative charge is formed when $\mathrm{pH}_{\mathrm{pzc}}$ is lower than the solution $\mathrm{pH}{ }^{43}$ The zero charge point for catalyst was 8.5. Tabit et al. investigated the activation of PMS by $\mathrm{CoFe}_{2} \mathrm{O}_{4}$ nanoparticles supported on graphene oxide, and found that the high degradation efficiency at $\mathrm{pH}$ of 7 was due to electrostatic adsorption between the negative charge of the catalyst and the positive charge of rhodamine $\mathrm{B} .{ }^{44}$ In addition, Zhang et al. observed the same results for removing ibuprofen by activating the PMS using $\mathrm{Fe}_{3} \mathrm{C}$ immobilized on carbon..$^{45}$

At lower $\mathrm{pH}$ values $(<7)$, decrease in the removal efficiency may be related to the high stability of PMS (eqn (6)) and lack of its proper reaction with metal ions. ${ }^{16}$ In addition, at the acidic $\mathrm{pH}$, the formation of the $\mathrm{H}$ bond between the hydrogen ion and the O-O group of PMS is led to decrease the positive charge of PMS, thus hindering the reaction between the PMS and the catalyst surface. ${ }^{29}$ Huang et al. investigated the degradation of reactive black B by the PMS/Co process and reported that, by increasing $\mathrm{pH}$ from 3.5 to 6 , the dye degradation efficiency was increased. They explained the low efficiency in acid $\mathrm{pH}$ based on the scavenging effect of the $\mathrm{H}^{+}$ ion for $\mathrm{SO}_{4}^{\cdot}$ and $\cdot \mathrm{OH}$ (eqn (7) and (8)). ${ }^{40}$ In addition, similar results were observed in other studies that reported low degradation efficiency under acidic conditions using the graphite felt- $\mathrm{Fe}_{3} \mathrm{O}_{4} / \mathrm{PMS}^{46}$ and $\mathrm{PMS} / \mathrm{Co}_{3} \mathrm{O}_{4}$-graphene processes. ${ }^{47}$

Table 2 Activation energies of catalysts with PMS for pollutant removal ${ }^{a}$

\begin{tabular}{|c|c|c|c|c|c|}
\hline Catalysts & Pollutant & Condition & $\begin{array}{l}\text { Efficiency } \\
(\%)\end{array}$ & $E_{\mathrm{a}}\left(\mathrm{kJ} \mathrm{mol}^{-1}\right)$ & References \\
\hline $\mathrm{Fe}_{3} \mathrm{O}_{4}$ & Orange $\mathrm{G}$ dye & $\mathrm{DC}=0.5 \mathrm{~g} \mathrm{~L}^{-1}, \mathrm{PMS}=1 \mathrm{mM}, C_{\mathrm{p}}=0.1 \mathrm{mM}, \mathrm{pH}=3$ and $T=30 \mathrm{~min}$ & $\simeq 100$ & 54.8 & 60 \\
\hline $\begin{array}{l}\mathrm{Co}_{3} \mathrm{O}_{4} / \text { carbon- } \\
\text { aerogel }\end{array}$ & Phenol & $\mathrm{DC}=0.2 \mathrm{~g} \mathrm{~L}^{-1}, \mathrm{PMS}=2 \mathrm{~g} \mathrm{~L}^{-1}, C_{\mathrm{p}}=50 \mathrm{ppm}, \mathrm{pH}=4$ and $T=120 \mathrm{~min}$ & $\simeq 100$ & 62.9 & 61 \\
\hline $\mathrm{Co}_{3} \mathrm{O}_{4} / \mathrm{SBA}-15$ & Phenol & $\mathrm{DC}=0.2 \mathrm{~g} \mathrm{~L}^{-1}, \mathrm{PMS}=2 \mathrm{~g} \mathrm{~L}^{-1}, C_{\mathrm{p}}=30 \mathrm{ppm}, \mathrm{pH}=4$ and $T=180 \mathrm{~min}$ & $\simeq 100$ & 67.4 & 62 \\
\hline $\mathrm{Mn}_{3} \mathrm{O}_{4}-\mathrm{rGO}$ & Orange II dye & $\mathrm{DC}=0.05 \mathrm{~g} \mathrm{~L}^{-1}, \mathrm{PMS}=1.5 \mathrm{~g} \mathrm{~L}^{-1}, C_{\mathrm{p}}=60 \mathrm{ppm}, \mathrm{pH}=7$ and $T=120 \mathrm{~min}$ & $\simeq 80$ & 49.5 & 63 \\
\hline $\mathrm{Mn}_{2} \mathrm{O}_{3}$ cube & Phenol & $\mathrm{DC}=0.4 \mathrm{~g} \mathrm{~L}^{-1}, \mathrm{PMS}=2 \mathrm{~g} \mathrm{~L}^{-1}, C_{\mathrm{p}}=25 \mathrm{ppm}$, and $T=90 \mathrm{~min}$ & $\simeq 100$ & 61.2 & 64 \\
\hline $\mathrm{CoFe}_{2} \mathrm{O}_{4} / \mathrm{TNTs}$ & Phenol & $\mathrm{DC}=0.01 \mathrm{~g} \mathrm{~L}^{-1}, \mathrm{PMS}=3 \mathrm{~g} \mathrm{~L}^{-1}, C_{\mathrm{p}}=20 \mathrm{ppm}$, and $T=60 \mathrm{~min}$ & 97.2 & 70.56 & 65 \\
\hline MWCNTs-CoFe ${ }_{3} \mathrm{O}_{4}$ & DCF & $\mathrm{DC}=0.5 \mathrm{~g} \mathrm{~L}^{-1}, \mathrm{PMS}=4 \mathrm{mM}, C_{\mathrm{p}}=30 \mathrm{ppm}, \mathrm{pH}=7$ and $T=120 \mathrm{~min}$ & 99.04 & 22.93 & This work \\
\hline
\end{tabular}

${ }^{a} T=$ time; $\mathrm{DC}=$ dosage of catalyst; $C_{\mathrm{p}}=$ initial pollutant concentration. 

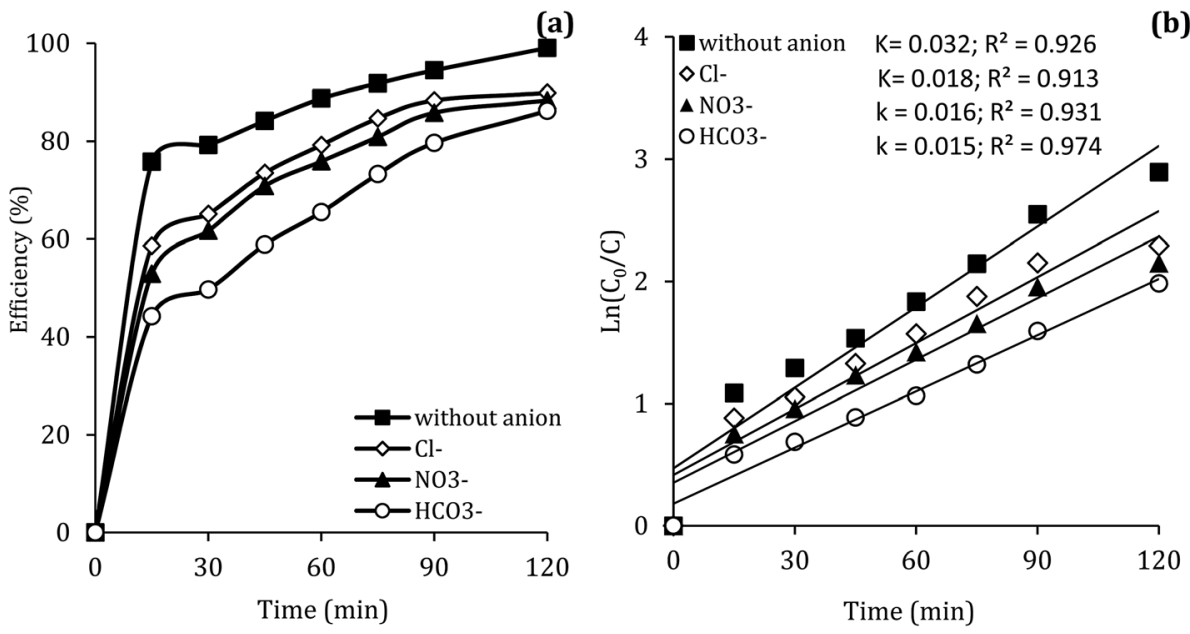

Fig. 11 Effect of various anions on the removal efficiency of DCF (a) and kinetic constant rate (b).

$$
\begin{gathered}
\mathrm{Co}^{2+}+\mathrm{HSO}_{5}^{-} \leftrightarrow \mathrm{CoSO}_{5}+\mathrm{H}^{+} \\
\cdot \mathrm{OH}+\mathrm{H}^{+}+\mathrm{e}^{-} \rightarrow \mathrm{H}_{2} \mathrm{O} \\
\mathrm{SO}_{4}^{-\cdot}+\mathrm{H}^{+}+\mathrm{e}^{-} \rightarrow \mathrm{HSO}_{4}^{-\cdot}
\end{gathered}
$$

At higher $\mathrm{pH}$ values $(>7)$, the reduction in efficiency can be due to the electrostatic repulsion between the MWCNTs$\mathrm{CoFe}_{3} \mathrm{O}_{4}$ catalyst surface and the dominant PMS species as $\mathrm{SO}_{5}{ }^{2-}{ }^{48}$ In addition, previous studies reported that at alkaline $\mathrm{pH}$, the PMS is decomposed through its non-radical pathways and generates less reactive species. ${ }^{49} \mathrm{Xu}$ et al. investigated the performance of graphene-CoFe $\mathrm{O}_{4}$ as a PMS activator for the degradation of dimethyl phthalate and found that, by increasing the initial $\mathrm{pH}$ from 4 to 11, the degradation efficiency of the pollutant is reduced due to the conversion of $\mathrm{SO}_{4}^{-}$into oxidants with low oxidation potential such as - O- (eqn (9) and (10)). ${ }^{16}$ In addition, the findings are similar to those observed in $\mathrm{CoFe}_{2} \mathrm{O}_{4} / \mathrm{PMS}$, ${ }^{50}$ ordered mesoporous- $\mathrm{MnFe}_{2} \mathrm{O}_{4} / \mathrm{PMS}^{51}$ and $\mathrm{Al}_{2} \mathrm{O}_{3}-\mathrm{CoFe}_{2} \mathrm{O}_{4} / \mathrm{PMS}$ processes. ${ }^{52}$

$$
\begin{gathered}
\mathrm{SO}_{4}{ }^{-\cdot}+\mathrm{OH}^{-} \rightarrow \mathrm{SO}_{4}{ }^{2-}+\cdot \mathrm{OH} \\
\cdot \mathrm{OH}+\mathrm{H}_{2} \mathrm{O} \rightarrow \cdot \mathrm{O}^{-}+\mathrm{H}_{3} \mathrm{O}^{+}
\end{gathered}
$$

\section{Effect of MWCNTs-CoFe $\mathrm{O}_{3}$ dosage}

Fig. 7 shows the effect of the MWCNTs-CoFe ${ }_{3} \mathrm{O}_{4}$ dosage on the DCF removal efficiency at pH of 7, PMS of $2 \mathrm{mM}$ and DCF of $30 \mathrm{mg} \mathrm{L}^{-1}$. According to this figure, by increasing the catalyst dosage from $25 \mathrm{mg} \mathrm{L}^{-1}$ to $500 \mathrm{mg} \mathrm{L}^{-1}$, the DCF removal efficiency was increased from $65.09 \%$ to $96.02 \%$ at $120 \mathrm{~min}$ of reaction. However, increasing the amount of MWCNTs-CoFe ${ }_{3} \mathrm{O}_{4}$ to values greater than $1000 \mathrm{mg} \mathrm{L}^{-1}$ is led to diminishing the efficiency to $87.93 \%$. Table 1 shows the first-order kinetic constant rate for the effect of the catalyst dosage. As can be seen, at the catalyst dosage of $500 \mathrm{mg} \mathrm{L}^{-1}$, the kinetic constant rate was $0.024 \mathrm{~min}^{-1}$, while the kinetic rate was obtained to be $0.010 \mathrm{~min}^{-1}$ at the catalyst dosage of $1000 \mathrm{mg} \mathrm{L}^{-1}$. The increase in removal efficiency can be related to increasing the adsorption
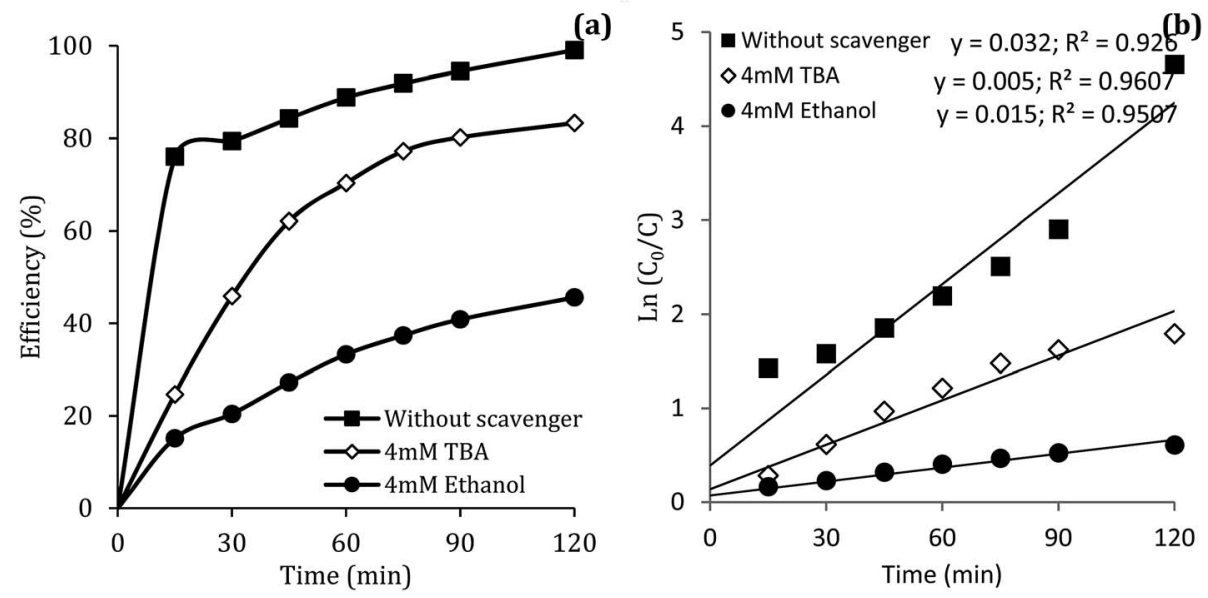

Fig. 12 Influence of TBA and ethanol on the removal efficiency of DCF (a) and kinetic constant rate (b). 

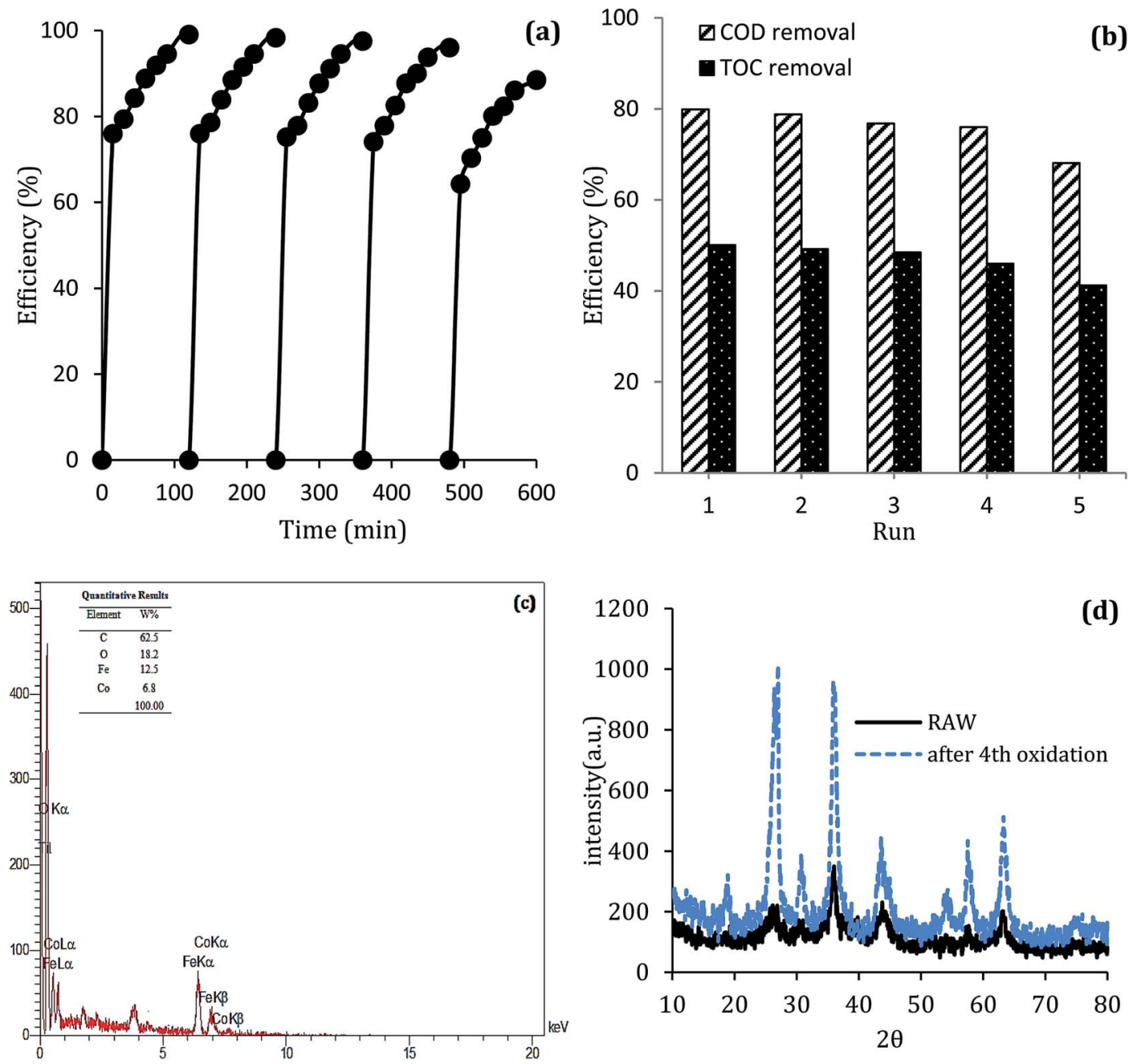

Fig. 13 (a) Catalytic performance of recycled MWCNTs-CoFe $\mathrm{O}_{4}$ for DCF removal, (b) COD and TOC removal; (c) EDS analysis and (d) XRD pattern of MWCNTs-CoFe $\mathrm{O}_{4}$ after the 4th cycle of DCF removal.

sites as well as providing the more active catalytic surface for activation of PMS to produce more active radical species. ${ }^{29,30}$ Decreasing the efficiency can be due to the accumulation of nanoparticles and the scavenging effect of the $\mathrm{Fe}_{3} \mathrm{O}_{4}$ nanoparticles on $\mathrm{SO}_{4} \cdot{ }^{29}$ Yan et al. studied the degradation of trichloroethylene using persulfate activated by graphene oxide/ $\mathrm{Fe}_{3} \mathrm{O}_{4}$, and found that, by increasing catalyst dose, degradation efficiency was initially increased and then reduced at the higher catalyst values. The authors explained the reduction in efficiency based on the consumption of $\mathrm{SO}_{4}^{\circ}$ by extra iron ions (eqn (11)) and persulfate produced in high concentration of sulfate radical (eqn (12) and (13)). ${ }^{53}$ Feng et al. reported that by increasing the $\mathrm{CuCo}_{2} \mathrm{O}_{4}$ catalyst dosage to values more than $0.08 \mathrm{~g} \mathrm{~L} \mathrm{~L}^{-1}$, the sulfamethazine degradation efficiency was decreased due to the scavenger effects of $\mathrm{Co}$ and $\mathrm{Cu}$ on $\mathrm{SO}_{4}^{\circ}$ and - OH (53). ${ }^{43}$ In addition, similar results were obtained in the degradation of carbamazepine by the $\mathrm{Mn}_{x} \mathrm{Co}_{3-x} \mathrm{O}_{4}$ nanocages/ PMS system ${ }^{54}$ and the degradation of 4-chlorophenol by the $\mathrm{Fe}_{3} \mathrm{O}_{4}-\mathrm{MnO}_{2} /$ PMS process. ${ }^{29}$

$$
\mathrm{Fe}^{2+}+\mathrm{SO}_{4}{ }^{--} \rightarrow \mathrm{Fe}^{3+}+\mathrm{SO}_{4}{ }^{2-}
$$

$$
\begin{gathered}
\mathrm{SO}_{4}{ }^{--}+\mathrm{SO}_{4}{ }^{\cdot-} \rightarrow \mathrm{S}_{2} \mathrm{O}_{8}{ }^{2-} \\
\mathrm{SO}_{4}{ }^{--}+\mathrm{S}_{2} \mathrm{O}_{8}{ }^{2-} \rightarrow \mathrm{SO}_{4}{ }^{2-}+\mathrm{S}_{2} \mathrm{O}_{8}{ }^{\cdot-}
\end{gathered}
$$

\section{The effect of PMS dosage}

Fig. 8 shows the effect of PMS dosage on DCF removal at pH of 7, MWCNTs-CoFe $\mathrm{O}_{4}$ of $500 \mathrm{mg} \mathrm{L}^{-1}$, DCF of $30 \mathrm{mg} \mathrm{L}^{-1}$. When the PMS dosage increased from 0.25 to $4 \mathrm{mM}$, the removal efficiency was rapidly increased from $64.26 \%$ to $99.047 \%$, and then it was dramatically diminished from $91.86 \%$ to $86.95 \%$ when the PMS dosage increased from 6 to $8 \mathrm{mM}$. In Table 1, the kinetic constant rate increased from 0.009 to $0.032 \mathrm{~min}^{-1}$ by an increase in PMS dosage from 0.25 to $4 \mathrm{mM}$, and then decreased with a further increase in PMS to $8 \mathrm{mM}$. An initial increase in removal efficiency can be due to the production of high levels of $\mathrm{SO}_{4}^{\cdot}$ and $\cdot \mathrm{OH}$ through the reaction of PMS and MWCNTs$\mathrm{CoFe}_{3} \mathrm{O}_{4}$. However, decreasing the efficiency can be related to the effect of PMS scavenging on $\mathrm{SO}_{4}^{-}$and $\cdot \mathrm{OH}$ (eqn (14) and 


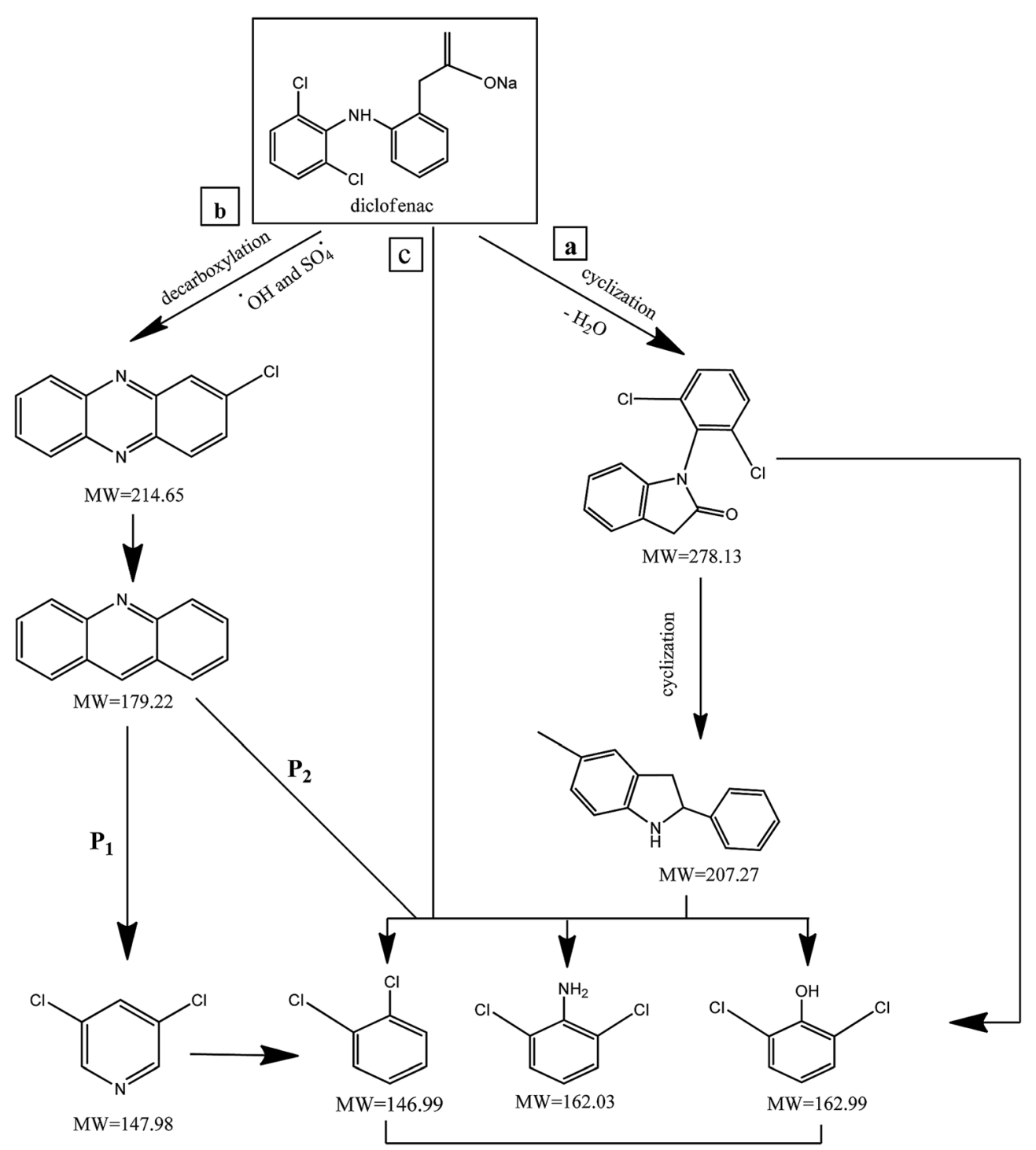

Fig. 14 The degradation pathways of DCF in MWCNTs-CoFe $\mathrm{O}_{4} / \mathrm{PMS}$ process.

(15)). ${ }^{51,55}$ Similar results were observed by Wei et al. ${ }^{56}$ and $\mathrm{Xu}$ et al. ${ }^{57}$ for degradation of dyes using the OMS- $\mathrm{Fe}_{3} \mathrm{O}_{4} / \mathrm{PMS}$ system and $\mathrm{Fe}_{3} \mathrm{O}_{4} @ \mathrm{C}-\mathrm{Co} / \mathrm{PMS}$ system, respectively.

$$
\begin{gathered}
\mathrm{SO}_{4}{ }^{\cdot-}+\mathrm{HSO}_{5}{ }^{-} \rightarrow \mathrm{SO}_{5}{ }^{--}+\mathrm{HSO}_{4}{ }^{-} \\
\cdot \mathrm{OH}+\mathrm{HSO}_{5}{ }^{-} \rightarrow \mathrm{SO}_{5}{ }^{-}+\mathrm{H}_{2} \mathrm{O}
\end{gathered}
$$

\section{Effect of initial concentration of DCF}

The effect of the initial concentration of DCF on the DCF removal efficiency was investigated at $\mathrm{pH}$ of $7, \mathrm{MWCNTs}-\mathrm{CoFe}_{3} \mathrm{O}_{4}$ of $500 \mathrm{mg} \mathrm{L}^{-1}$ and PMS of $4 \mathrm{mM}$. As shown in Fig. 9, by increasing the initial concentration of DCF from 10 to $50 \mathrm{mg} \mathrm{L}^{-1}$, the DCF removal efficiency was decreased from $99.40 \%$ to $76.99 \%$ at $120 \mathrm{~min}$. The kinetics analysis results in Table 1 show the same trend in DCF removal efficiency. The kinetic constant rate decreased from 0.038 to $0.012 \mathrm{~min}^{-1}$ when the DCF concentration increased from 10 to $50 \mathrm{mg} \mathrm{L}^{-1}$. This reduction in efficiency can be related to the low concentration of $\mathrm{SO}_{4}^{\cdot}$ and $\cdot \mathrm{OH}$ produced as well as the competition between intermediates with main molecules for ROSs. ${ }^{54}$ Tan et al. by studying the acetaminophen degradation using the PMS-activated by $\mathrm{Fe}_{3} \mathrm{O}_{4}$ nanoparticles, reported that increasing the concentration of acetaminophen from 2 to $10 \mathrm{mg} \mathrm{L}^{-1}$ reduced its degradation efficiency from $100 \%$ to $74.7 \%$. The authors explained the decrease in efficiency by this fact that the constant amount of ROSs is produced, when all the factors (pH, PMS, and catalyst) are constant. This number of reactive species produced has the ability to eliminate and to degrade a specific amount of contaminants. Therefore, if the initial concentration of the pollutant is increased, the number of reactive species existed in the environment is not sufficient to remove excessive molecules of contaminant..$^{30}$ In addition, similar results were reported for the degradation of phenol using heterogeneous activation of PMS by graphene- $\mathrm{Co}_{3} \mathrm{O}_{4} \cdot{ }^{58}$ 
Fig. 9 also shows that, at different reaction times, the system efficiency for concentrations of 10 to $30 \mathrm{mg} \mathrm{L}^{-1}$ is approximately similar. This finding shows that the process of PMS activated by MWCNTs- $\mathrm{CoFe}_{3} \mathrm{O}_{4}$ is suitable for removal of high concentrations of DCF. A similar trend was reported by Zhou et al. for the degradation of 2,4-dichlorophenol. ${ }^{59}$

\section{The effect of temperature}

Fig. 10 shows the effect of the solution temperature on DCF removal at $\mathrm{pH}$ of $7, \mathrm{MWCNTs}-\mathrm{CoFe}_{3} \mathrm{O}_{4}$ of $500 \mathrm{mg} \mathrm{L}^{-1}$, PMS of $4 \mathrm{mM}$, and DCF of $30 \mathrm{mg} \mathrm{L}^{-1}$. As shown in Fig. 10a, with increasing the temperature from 10 to $30{ }^{\circ} \mathrm{C}$, the efficiency of DCF removal increases from $86.83 \%$ to $99.04 \%$ at the reaction time of $120 \mathrm{~min}$. The kinetic analysis results in Table 1 confirmed this trend. This increase in degradation efficiency can be attributed to decomposing the $\mathrm{O}-\mathrm{O}$ band in PMS and producing more $\mathrm{SO}_{4}^{\cdot}$ and $\cdot \mathrm{OH}$. To further confirm the results, the effect of temperature without catalyst at various temperatures was investigated. The results showed that by increasing the temperature from 10 to $30{ }^{\circ} \mathrm{C}$, the DCF removal efficiency was increased from 0 to $21.5 \%$ at the reaction time of $120 \mathrm{~min}$ (Fig. 10b). Similar results were obtained in the study of carbamazepine degradation using PMS activated by $\mathrm{Mn}_{x} \mathrm{Co}_{3-x} \mathrm{O}_{4}$ nanocages. ${ }^{54}$

The relationship between constant rate and temperature can be evaluated by plotting $\ln (K)$ versus $1 / T$, according to the Arrhenius equation ( $\ln K=\ln A-E / R T)$. In this equation, $K$ is the constant rate, $R$ is the global gas constant $\left(8.314 \mathrm{~kJ} \mathrm{~mol}^{-1}\right), T$ is the temperature, $E_{\mathrm{a}}$ is the activation energy $\left(\mathrm{kJ} \mathrm{mol}^{-1}\right)$ and $A$ is constant. Linking the $k$ values of the first order kinetic and the Arrhenius equation, PMS activation energy by MWCNTs-CoFe $\mathrm{O}_{4}$ was found to be $22.93 \mathrm{~kJ} \mathrm{~mol}^{-1}$. This amount of $E_{\mathrm{a}}$ calculated in this study was much lower than the $E_{\mathrm{a}}$ values reported in other studies (Table 2), which represent a promising catalytic material for the oxidation processes of pharmaceutical compounds, especially DCF. Table 2 also shows that the low dosages of MWCNTs$\mathrm{CoFe}_{3} \mathrm{O}_{4}$ at neutral $\mathrm{pH}$ have a catalytic activity similar to other catalysts used in the activation of PMS. Therefore, the PMS/ MWCNTs-CoFe ${ }_{3} \mathrm{O}_{4}$ system can be used as a new catalytic process for degradation of DCF.

\section{The effect of anions}

In the body of real water, there are various anions, such as bicarbonate $\left(\mathrm{HCO}_{3}{ }^{-}\right)$, nitrate $\left(\mathrm{NO}_{3}{ }^{-}\right)$and chloride $\left(\mathrm{Cl}^{-}\right)$, which they can cause the consumption of ROSs and free radical-induced wastewater treatment reaction. ${ }^{66}$ Therefore, in the present study, the DCF removal efficiency in the presence of various anions was investigated at $\mathrm{pH}$ of $7, \mathrm{MWCNTs}-\mathrm{CoFe}_{3} \mathrm{O}_{4}$ of $500 \mathrm{mg} \mathrm{L}^{-1}$, PMS of $4 \mathrm{mM}$ and DCF of $30 \mathrm{mg} \mathrm{L}^{-1}$. As shown in Fig. 11a, the DCF removal efficiency was $89.88 \%, 88.36 \%$ and $86.24 \%$ in presence of $\mathrm{Cl}^{-}, \mathrm{NO}_{3}{ }^{-}$and $\mathrm{HCO}_{3}{ }^{-}$at $120 \mathrm{~min}$, respectively. The results of Fig. $11 \mathrm{~b}$ also shows that the kinetic constant rate was decreased from $0.032 \mathrm{~min}^{-1}$, at the condition without the presence of anion, to $0.018,0.016$ and 0.015 , at the presence of $\mathrm{Cl}^{-}, \mathrm{NO}_{3}{ }^{-}$and $\mathrm{HCO}_{3}{ }^{-}$, respectively. This could be due to the reaction of anions with $\mathrm{SO}_{4}^{-}$ and the production of reactive species with lower oxidation potential. The similar limiting effect of the anions on the activation of PMS by various catalysts was reported by Zhao et al. ${ }^{67}$ and Tan et al. ${ }^{68}$

\section{Reactive species}

Previous studies have shown that $\mathrm{SO}_{4}^{\cdot}$ and $\cdot \mathrm{OH}$ can be produced by homogeneous or heterogeneous activation of PMS. It has also been reported in these studies that TBA is used as $\cdot \mathrm{OH}$ scavenger and ethanol is the scavenger for both $\mathrm{SO}_{4}^{\cdot}$ and $\cdot \mathrm{OH}$. Thus, in the present study, the reactive species are probed using TBA and ethanol. As can be seen in Fig. 12a, DCF removal is significantly reduced in the presence of scavengers compared to the original system without ethanol and TBA. Moreover, the addition of ethanol has a high limiting efficiency compared to TBA. The results of the kinetic constant rate in Fig. 11b show that the kinetic constant of the ethanol-containing system $\left(0.005 \mathrm{~min}^{-1}\right)$ is much lower than the system containing TBA $\left(0.015 \mathrm{~min}^{-1}\right)$ and the system without scavengers $\left(0.032 \mathrm{~min}^{-1}\right)$. Therefore, the above results suggest that both $\mathrm{SO}_{4}^{\cdot}$ and $\cdot \mathrm{OH}$ radicals have been produced by PMS activation during the DCF oxidation process and the $\mathrm{SO}_{4}^{-}$radical was the main species.

\section{Reusability of MWCNTs-CoFe $\mathrm{O}_{4}$}

The stability of catalyst in catalytic oxidation systems is one of the critical parameters for the ability to recycling the catalyst based on process cost in practical applications. For further studying the stability and reusability of the MWCNTs-CoFe ${ }_{3} \mathrm{O}_{4}$ catalyst, recycling experiments were performed with centrifuge steps, drying with nitrogen gas and re-dispersing in a DCFcontaining solution. As can be seen in Fig. 13a, by increasing the number of runs, the DCF removal efficiency was slowly decreased. After the fourth run, the DCF removal efficiency decreased from $99.04 \%$ to $88.46 \%$, while the TOC removal rate decreased from $50.11 \%$ to $41.23 \%$. Both of these changes show the reusability of the MWCNTs-CoFe $\mathrm{O}_{4}$ catalyst in the heterogeneous activation of PMS. In addition, the decrease in efficiency after the fourth run may be due to leaching of iron and cobalt from the catalyst surface, as well as the occupation of reactive sites of the catalyst by intermediates produced during DCF degradation. The results of Fig. 13c confirmed these results. According to this figure, the weight percentage of iron and cobalt has decreased compared to the raw material synthesized (Fig. 2c).

To investigate the stability of the MWCNTs- $\mathrm{CoFe}_{3} \mathrm{O}_{4}$ catalyst structure, $\mathrm{XRD}$ analysis also was performed on the raw material and recycled after four runs of experiments. The results in Fig. 13d show the similar structure and phase of the catalyst before and after the catalytic process. These findings indicate that MWCNTs-CoFe $\mathrm{O}_{4}$ has a high potential for reuse and application in catalytic degradation of organic pollutants such as DCF.

\section{DCF degradation pathways}

In order to understand the DCF degradation mechanism through PMS activated by the MWCNTs-CoFe ${ }_{3} \mathrm{O}_{4}$ catalyst, the intermediates were analyzed using the GC-MS technique. 
Fig. 14 shows the pathways and byproducts for DCF degradation. According to this figure, there are three reaction pathways for DCF degradation. In pathway a, DCF can be converted to (2,6-diclorophenyl) indolin-2-one through the intramolecular condensation and loss of $\mathrm{H}_{2} \mathrm{O}$. Then, this byproduct can be transformed into 5-methyl-2-phenyl-1 $H$-indole through the cyclization process. Finally, by attack of reactive species $\left(\mathrm{SO}_{4}^{*}\right.$ and $\cdot \mathrm{OH}$ ) and cleavage of the $\mathrm{C}-\mathrm{N}$ bond, 5-methyl-2-phenyl- $1 \mathrm{H}$ indole is oxidized to 2,6-dichlorophenol, 2,6-dichloroaniline and $O$-dichlorobenzene.

Alternatively, (2,6-dichlorophenyl)-indolin-2-one, during reactive species attack to the $\mathrm{C}-\mathrm{N}$ chain, may directly lead to 2,6dichlorophenol, 2,6-dichloroaniline and $O$-dichlorobenzene in the reaction solution. The similar reaction mechanism was reported for DCF degradation by Bae et al. ${ }^{69}$ and Pourzamani et $a .^{21}$ In the reaction pathway b, 2-chlorophenazine is formed by reactive species attack and decarboxylation process of DCF. This intermediate is then oxidized to 3,4-dichloropyridine $\left(\mathrm{P}_{1}\right)$, and byproducts of 2,6-dichlorophenol, 2,6-dichloroaniline and $O$-dichlorobenzene $\left(\mathrm{P}_{2}\right)$ through reactive species attack and the $\mathrm{C}-\mathrm{N}$ bond cleavage. In pathway $\mathrm{b}, 3$,4-dichloropyridine can also be converted to $O$-dichlorobenzene during the oxidation process by losing $\mathrm{NH}_{3}$. In the pathway c, intermediates of 2,6dichlorophenol, 2,6-dichloroaniline and $O$-dichlorobenzene can be formed by cleavage of $\mathrm{C}-\mathrm{N}$ bond of the DCF by reactive species attack.

\section{Conclusion}

In the present study, $\mathrm{CoFe}_{3} \mathrm{O}_{4}$-supported MWCNTs magnetic nanoparticles were synthesized using a co-precipitation method and were first used to activate the PMS and to degrade the DCF. The results of the comparative tests showed that the MWCNTs$\mathrm{CoFe}_{3} \mathrm{O}_{4} / \mathrm{PMS}$ system has high catalytic activity in the degradation of DCF compared to other systems. This increase in efficiency was due to the capability of each material present in the MWCNTs-CoFe ${ }_{3} \mathrm{O}_{4}$ catalyst to activate PMS. The highest removal efficiencies of DCF (99.04\%), COD (79.89\%) and TOC $(50.11 \%)$ were achieved at pH of 7, PMS dosage of $4 \mathrm{mM}$, catalyst dosage of $500 \mathrm{mg} \mathrm{L}^{-1}$, DCF concentration of $30 \mathrm{mg} \mathrm{L}^{-1}$ and time of 120 min. Meanwhile, anions $\left(\mathrm{NO}_{3}{ }^{-}, \mathrm{Cl}^{-}\right.$and $\left.\mathrm{HCO}_{3}{ }^{-}\right)$showed the hindering effect on DCF removal and the order of hindering was $\mathrm{HCO}_{3}{ }^{-}>\mathrm{NO}_{3}{ }^{-}>\mathrm{Cl}^{-}$. The relationship between temperature and constant rate showed that the MWCNTs-CoFe ${ }_{3} \mathrm{O}_{4}$ catalyst requires less activation energy than other catalyst used in previous studies. In addition, the results of the scavenging experiment suggested that both $\mathrm{SO}_{4}^{\cdot}$ and $\cdot \mathrm{OH}$ were produced in the MWCNTs-CoFe ${ }_{3} \mathrm{O}_{4} / \mathrm{PMS}$ system and $\mathrm{SO}_{4}^{\circ}$ was the dominant reactive species for DCF removal. The catalytic stability of MWCNTs-CoFe ${ }_{3} \mathrm{O}_{4}$ more than 4 times showed the reusability for long-term DCF catalytic degradation. The dichlorophenol, 2,6dichloroaniline and $O$-dichlorobenzene were identified as the main intermediates by GC-MS analysis and the DCF degradation pathways were proposed based on the identification of intermediates. Finally, based on the high stability, low activation energy and easy synthesis, it can be concluded that MWCNTs-CoFe ${ }_{3} \mathrm{O}_{4}$ is a promising alternative for conventional heterogeneous catalysts for activating PMS in the catalytic degradation process of DCF.

\section{Conflicts of interest}

There are no conflicts to declare.

\section{Acknowledgements}

This work was supported by the Environmental Health Research Center of Golestan University of Medical Sciences (No. 97032949).

\section{References}

1 C. Martínez, M. Fernández, J. Santaballa and J. Faria, Appl. Catal., B, 2011, 107, 110-118.

2 H. Yu, E. Nie, J. Xu, S. Yan, W. J. Cooper and W. Song, Water Res., 2013, 47, 1909-1918.

3 H. Sanderson, D. J. Johnson, T. Reitsma, R. A. Brain, C. J. Wilson and K. R. Solomon, Regul. Toxicol. Pharmacol., 2004, 39, 158-183.

4 X. Lu, Y. Shao, N. Gao, J. Chen, Y. Zhang, H. Xiang and Y. Guo, Ecotoxicol. Environ. Saf., 2017, 141, 139-147.

5 Y. Zhang, S.-U. Geißenand and C. Gal, Chemosphere, 2008, 73, 1151-1161.

6 J. Madhavan, P. S. S. Kumar, S. Anandan, M. Zhou, F. Grieser and M. Ashokkumar, Chemosphere, 2010, 80, 747-752.

7 H. Boukhatem, H. Khalaf, L. Djouadi, Z. Marin, R. M. Navarro, J. A. Santaballa and M. Canle, J. Environ. Chem. Eng., 2017, 5, 5636-5644.

8 L. Lonappan, S. K. Brar, R. K. Das, M. Verma and R. Y. Surampalli, Environ. Int., 2016, 96, 127-138.

9 S. Lu, G. Wang, S. Chen, H. Yu, F. Ye and X. Quan, J. Hazard. Mater., 2018, 353, 401-409.

10 X. Pang, Y. Guo, Y. Zhang, B. Xu and F. Qi, Chem. Eng. J., 2016, 304, 897-907.

11 J. Deng, C. Ya, Y. Ge, Y. Cheng, Y. Chen, M. Xu and H. Wang, RSC Adv., 2018, 8, 2338-2349.

12 H. Zhang, X. Liu, J. Ma, C. Lin, C. Qi, X. Li, Z. Zhou and G. Fan, J. Hazard. Mater., 2018, 344, 1220-1228.

13 W. Guo, S. Su, C. Yi and Z. Ma, Environ. Prog. Sustainable Energy, 2013, 32, 193-197.

14 P. Shukla, S. Wang, K. Singh, H. M. Ang and M. O. Tadé, Appl. Catal., B, 2010, 99, 163-169.

15 T. Huang, J. Chen, Z. Wang, X. Guo and J. C. Crittenden, Environ. Sci. Pollut. Res., 2017, 24, 9651-9661.

16 L. J. Xu, W. Chu and L. Gan, Chem. Eng. J., 2015, 263, 435443.

17 Y.-P. Zhu, T.-Z. Ren and Z.-Y. Yuan, RSC Adv., 2015, 5, 76287636.

18 Y. Zhu, S. Chen, X. Quan and Y. Zhang, RSC Adv., 2013, 3, 520-525.

19 M. F. L. De Volder, S. H. Tawfick, R. H. Baughman and A. J. Hart, Science, 2013, 339, 535-539.

20 I. Lerman, Y. Chen, B. Xing and B. Chefetz, Environ. Pollut., 2013, 182, 169-176. 
21 H. Pourzamani, Y. Hajizadeh and N. Mengelizadeh, Process Saf. Environ. Prot., 2018, 119, 271-284.

22 H. Pourzamani, N. Mengelizadeh, Y. Hajizadeh and H. Mohammadi, Environ. Sci. Pollut. Res., 2018, 25, 2474624763.

23 J. Safari and Z. Zarnegar, J. Ind. Eng. Chem., 2014, 20, 22922297.

24 C. Y. Su, B. H. Liu, T. J. Lin, Y. M. Chi, C. C. Kei, K. W. Wang and T. P. Perng, J. Mater. Chem. A, 2015, 3, 18983-18990.

25 F. Ghanbari and N. Jaafarzadeh, Res. Chem. Intermed., 2017, 43, 4623-4637.

26 Y. Wang, H. Sun, H. M. Ang, M. O. Tadé and S. Wang, Chem. Eng. J., 2014, 245, 1-9.

27 J.-L. Gong, B. Wang, G.-M. Zeng, C.-P. Yang, C.-G. Niu, Q.-Y. Niu, W.-J. Zhou and Y. Liang, J. Hazard. Mater., 2009, 164, 1517-1522.

28 F. Gong, L. Wang, D. Li, F. Zhou, Y. Yao, W. Lu, S. Huang and W. Chen, Chem. Eng. J., 2015, 267, 102-110.

29 J. Liu, Z. Zhao, P. Shao and F. Cui, Chem. Eng. J., 2015, 262, 854-861.

30 C. Tan, N. Gao, Y. Deng, J. Deng, S. Zhou, J. Li and X. Xin, J. Hazard. Mater., 2014, 276, 452-460.

31 W.-D. Oh, S.-K. Lua, Z. Dong and T.-T. Lim, J. Hazard. Mater., 2015, 284, 1-9.

32 J. Deng, Y.-J. Chen, Y.-A. Lu, X.-Y. Ma, S.-F. Feng, N. Gao and J. Li, Environ. Sci. Pollut. Res., 2017, 24, 14396-14408.

33 F. Zhao, Y. Zou, X. Lv, H. Liang, Q. Jia and W. Ning, J. Chem. Eng. Data, 2015, 60, 1338-1344.

34 P. Shi, R. Su, S. Zhu, M. Zhu, D. Li and S. Xu, J. Hazard. Mater., 2012, 229-230, 331-339.

$35 \mathrm{X} . \mathrm{Hu}$ and Z. Cheng, Chin. J. Chem. Eng., 2015, 23, 1551-1556. 36 B. Czech and P. Oleszczuk, Chemosphere, 2016, 149, 272-278.

37 H. Zhao, J. Zhang, Q. Ye, H. Xu, G. Zhou, M. Wang and W. Deng, RSC Adv., 2018, 8, 17462-17470.

38 J. Chen, L. Zhang, T. Huang, W. Li, Y. Wang and Z. Wang, J. Hazard. Mater., 2016, 320, 571-580.

39 H. Lee, H.-J. Lee, J. Jeong, J. Lee, N.-B. Park and C. Lee, Chem. Eng. J., 2015, 266, 28-33.

40 Y.-H. Huang, Y.-F. Huang, C.-i. Huang and C.-Y. Chen, J. Hazard. Mater., 2009, 170, 1110-1118.

41 K. H. Chan and W. Chu, Water Res., 2009, 43, 2513-2521.

42 L. Hu, G. Zhang, M. Liu, Q. Wang, S. Dong and P. Wang, Sci. Total Environ., 2019, 647, 352-361.

43 Y. Feng, J. Liu, D. Wu, Z. Zhou, Y. Deng, T. Zhang and K. Shih, Chem. Eng. J., 2015, 280, 514-524.

44 R. Tabit, O. Amadine, Y. Essamlali, K. Dânoun, A. Rhihil and M. Zahouily, RSC Adv., 2018, 8, 1351-1360.

45 G. Zhang, Y. Ding, W. Nie and H. Tang, J. Environ. Sci., 2019, 78, 1-12.
46 M. Ahmadi and F. Ghanbari, Mater. Res. Bull., 2019, 111, 4352.

47 X. J. Zhou, P. H. Shi, Y. F. Qin, J. C. Fan, Y. L. Min and W. F. Yao, J. Mater. Sci.: Mater. Electron., 2016, 27, 10201030.

48 J. Deng, M. Xu, C. Qiu, Y. Chen, X. Ma, N. Gao and X. Li, Appl. Surf. Sci., 2018, 459, 138-147.

49 W. Qin, G. Fang, Y. Wang and D. Zhou, Chem. Eng. J., 2018, 348, 526-534.

50 J. Li, M. Xu, G. Yao and B. Lai, Chem. Eng. J., 2018, 348, 10121024.

51 J. Deng, S. Feng, X. Ma, C. Tan, H. Wang, S. Zhou, T. Zhang and J. Li, Sep. Purif. Technol., 2016, 167, 181-189.

52 Q. Wang, Y. Shao, N. Gao, W. Chu, J. Chen, X. Lu, Y. Zhu and N. An, Sep. Purif. Technol., 2017, 189, 176-185.

53 J. Yan, W. Gao, M. Dong, L. Han, L. Qian, C. P. Nathanail and M. Chen, Chem. Eng. J., 2016, 295, 309-316.

54 J. Deng, Y.-q. Cheng, Y.-a. Lu, J. C. Crittenden, S.-q. Zhou, N.-y. Gaoand and J. Li, Chem. Eng. J., 2017, 330, 505-517.

55 S. Muhammad, E. Saputra, H. Sun, J. d. C. Izidoro, D. A. Fungaro, H. M. Ang, M. O. Tadé and S. Wang, RSC Adv., 2012, 2, 5645-5650.

56 M. Wei, Y. Ruan, S. Luo, X. Li, A. Xu and P. Zhang, New J. Chem., 2015, 39, 6395-6403.

57 Z. Xu, J. Lu, Q. Liu, L. Duan, A. Xu, Q. Wang and Y. Li, RSC $A d v .$, 2015, 5, 76862-76874.

58 Y. Yao, Z. Yang, H. Sun and S. Wang, Ind. Eng. Chem. Res., 2012, 51, 14958-14965.

59 R. Zhou, J. Zhao, N. Shen, T. Ma, Y. Su and H. Ren, Chemosphere, 2018, 197, 670-679.

60 J. Zhang, M. Chen and L. Zhu, RSC Adv., 2016, 6, 4756247569.

61 Y. Hardjono, H. Sun, H. Tian, C. Buckley and S. Wang, Chem. Eng. J., 2011, 174, 376-382.

62 P. Shukla, H. Sun, S. Wang, H. M. Ang and M. O. Tadé, Catal. Today, 2011, 175, 380-385.

63 Y. Yao, C. Xu, S. Yu, D. Zhang and S. Wang, Ind. Eng. Chem. Res., 2013, 52, 3637-3645.

64 E. Saputra, S. Muhammad, H. Sun, H.-M. Ang, M. O. Tadé and S. Wang, Appl. Catal., B, 2014, 154, 246-251.

65 Y. Du, W. Ma, P. Liu, B. Zou and J. Ma, J. Hazard. Mater., 2016, 308, 58-66.

66 L. Hu, G. Zhang, M. Liu, Q. Wang and P. Wang, Chem. Eng. J., 2018, 338, 300-310.

67 Z. Zhao, J. Zhao and C. Yang, Chem. Eng. J., 2017, 327, 481489.

68 C. Tan, Y. Dong, D. Fu, N. Gao, J. Ma and X. Liu, Chem. Eng. J., 2018, 334, 1006-1015.

69 S. Bae, D. Kim and W. Lee, Appl. Catal., B, 2013, 134, 93-102. 